\title{
DISTRIBUIÇÃO DA VARIABILIDADE GENÉTICA EM AROEIRA (Myracrodruon urundeuva - Anacardiaceae) POR MARCADORES RAPD E POLIMORFISMO DE SEQUÊNCIAS DE cPDNA
}

\author{
ALESSANDRA MARIA MOREIRA REIS \\ Engenheiro Florestal
}

Orientador: Prof. Dr. DARIO GRATTAPAGLIA

Dissertação apresentada à Escola Superior de Agricultura "Luíz de Queiroz", Universidade de São Paulo, para obtenção do título de Mestre em Ciências, Área de : Concentração: Ciências Florestais

PIRACICABA

Estado de São Paulo - Brasil

Julho- 1999 


\section{Dados Internacionais de Catalogação na Publicação (CIP) DIVISÃo DE BIBLIOTECA E DOCUMENTAÇÃO - Campus "Luiz de Queiroz"/USP}

Reis, Alessandra Maria Moreira

Distribuição da variabilidade genética em aroeira (Myracrodruon urundeuva -

Anacardiaceae) por marcadores RAPD e polimorfismo de sequência de cpDNA / Alessandra Maria Moreira Reis. - Piracicaba, 1999.

60 p. : il.

Dissertação (mestrado) - - Escola Superior de Agricultura Luiz de Queiroz, 1999.

Bibliografia.

1. DNA de cloroplasto 2. Espécie florestal nativa 3. Genética de população 4. Germoplasma vegetal 5. Marcador molecular 6. Polimorfismo 7. Variabilidade genética I. Título

CDD 634.97328

Mermitida a copia total ou parcial deste documento, desde que citada a fonte 0 Autor" 


\section{AGRADECIMENTOS}

Aos meus pais, que sempre me apoiaram neste Mestrado, desde a idéia de ir para Piracicaba, até a pergunta: "Quando é que você vai defender?!";

Ao Dario, pela orientação, paciência, e, principalmente, pelo otimismo incrível que até faz a gente acreditar que tudo vai dar certo;

À CAPES e à FAPESP, pelas bolsas de estudo;

Ao Professor Paulo Kageyama e à Elza, por serem minha ligação com Piracicaba e a FAPESP;

Ao Pesquisador José Alves da Silva e à equipe do LPA pela disponibilização da coleção de germoplasma de aroeira;

À Antonieta Nassif Salomão, que me acompanha, torce (e dá palpites) desde a Iniciação Científica;

Ao Mário Moraes pela atenção e boa vontade em fornecer qualquer informação a respeito das populações de Paulo de Faria e Selvíria;

À Célia Cordeiro, pela enorme ajuda nas análises estatísticas;

Ao Luís Palhares e Sérgio Noronha pelas análises envolvendo geoprocessamento e confeç̧ão dos mapas;

Aos amigos da turma de Mestrado em Ciências Florestais 1996, pelos ótimos momentos que passamos juntos;

Aos Golf Boys, Cláudio, Ariel e Kibe, peios almoços de Domingo, para matar as saudades de Brasília;

Aos Amigos do Laboratório de Genética de Plantas pela ajuda nos momentos de desespero: Matias, Cláudio e Anders, no computador; Rosana e Ana, no sequenciamento; Rosane, nas discussões técnicas (dá-lhe,Wrigth!); Maristerra, minha "mãe" no Lab; Camila, Kleyne, Alexandre, Nei, Túlio e Rodrigo, pelo entusiasmo e "gás" da iniciação; Neide pelo apoio em tudo no Laboratório; e todo mundo do LABGEN, vocês são ótimos! 
De novo, à Rosana, Maris, Rosane, Isabel e Camila, porque o nosso relacionamento profissional se transformou em amizade, e tem um valor enorme para $\operatorname{mim}$;

À Lu, Tati , Sérgio e Raquel, " amigos de infância", que, tenho certeza, são para sempre;

À Andrea, Kátia e Cristiana, porque a ótima experiência de morar com vocês fez nascer uma amizade e cumplicidade que só tudo o que passamos juntas pode contar ("A intimidade é F");

À galera Out, sempre presente nas melhores farras (e micos) da minha vida e, principalmente, àqueles que são "Out prá sempre", sei que "sempre" é uma palavra forte, mas com vocês ela é válida a qualquer hora;

Sérgio, Alê, Soninha e Léo, por causa do nosso relaxante almoço de Domingo, eu quase não escrevia estes agradecimentos.... 


\section{SUMÁRIO}

Página

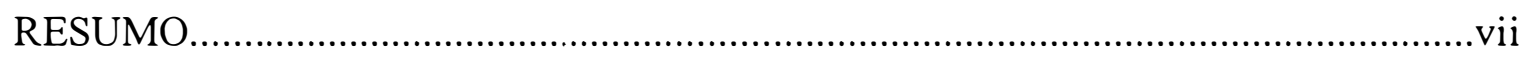

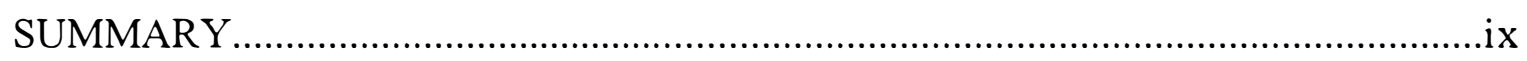

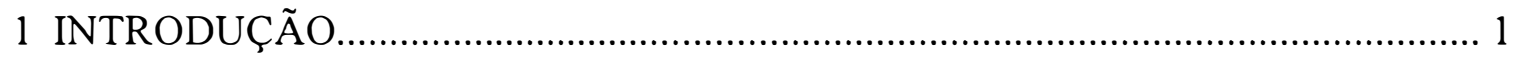

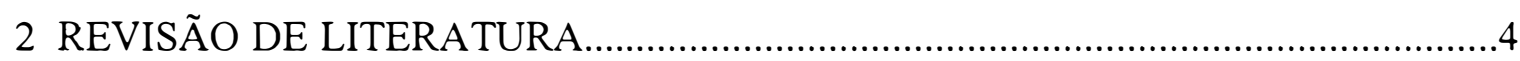

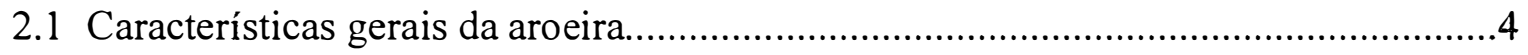

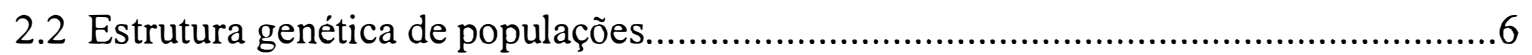

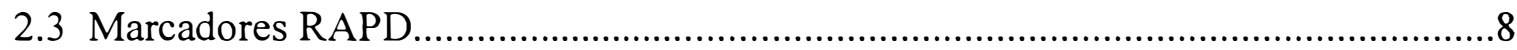

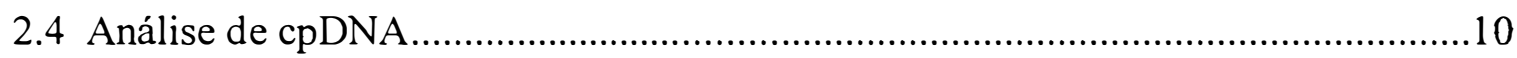

3 VARIABILIDADE GENÉTICA DE MARCADORES RAPD EM UM

BANCO DE GERMOPLASMA DE AROEIRA (Myracrodruon urundeuva

- Anacardiaceae): RECOMENDAÇÕES PARA A CONSERVAÇÃO..........................13

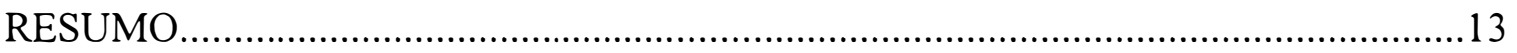

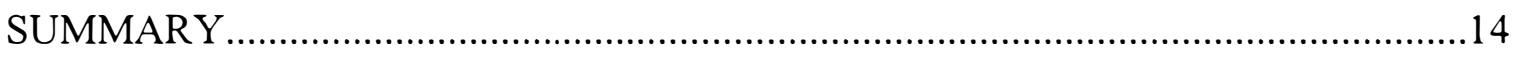

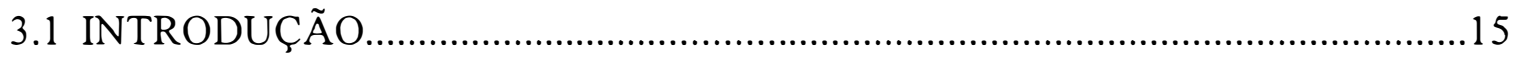

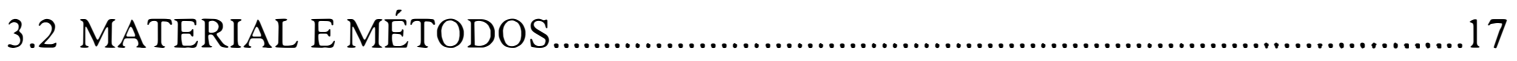

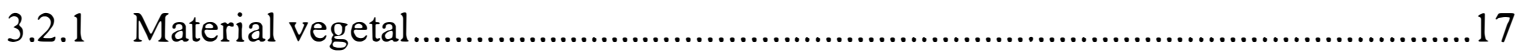

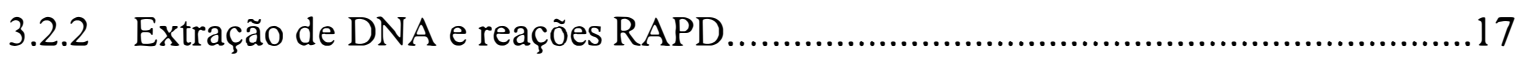

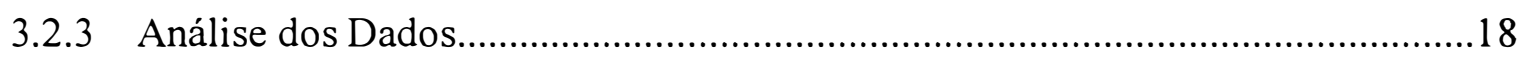

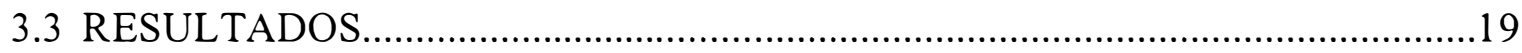

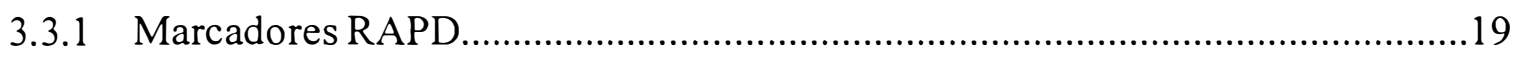

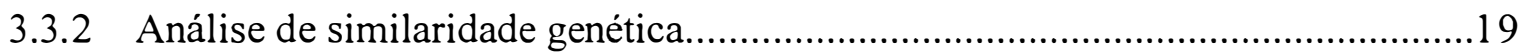

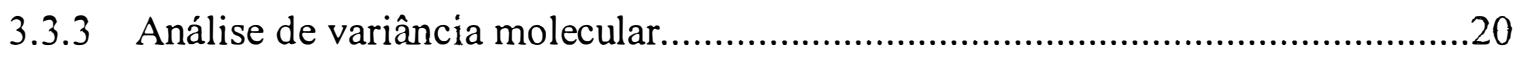

3.4 DISCUSSÃO

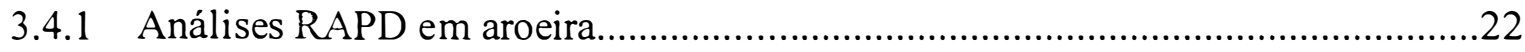

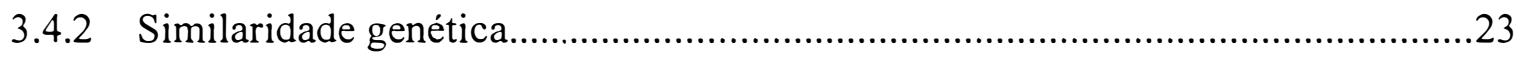

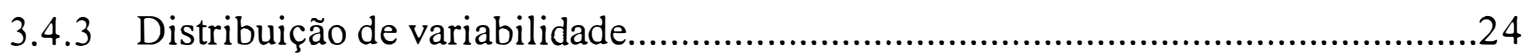

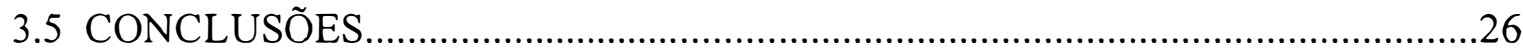


Página

4 DISTRIBUIÇÃO REGIONAL DA VARIABILIDADE EM RAPD E cpDNA DE AROEIRA (Myracrodruon urundeuva - Anacardiaceae).............................28

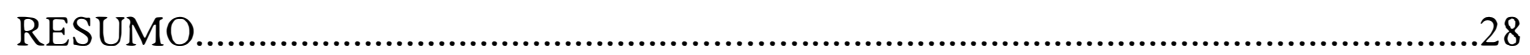

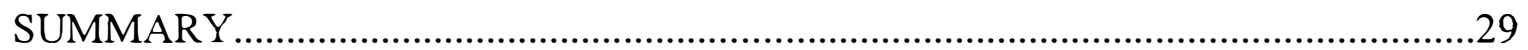

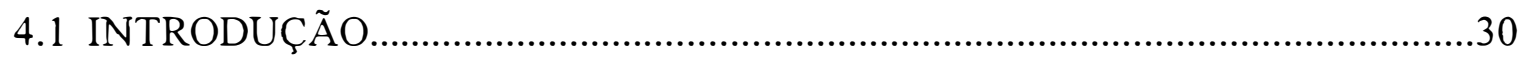

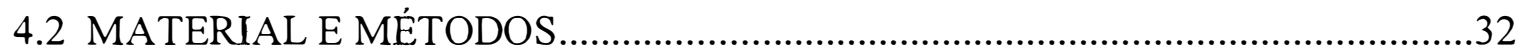

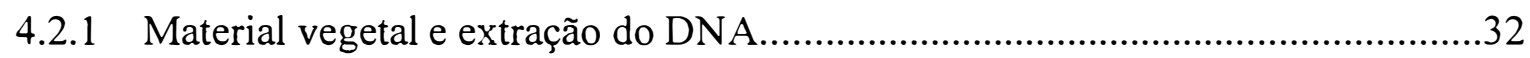

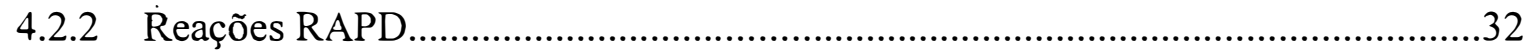

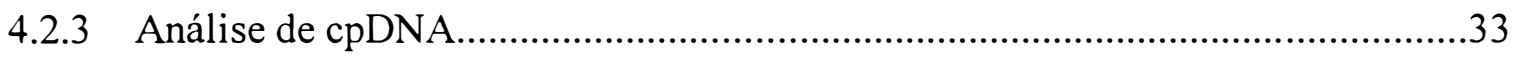

4.2.4 Análise de polimorfismo de inserção no cpDNA...................................................34

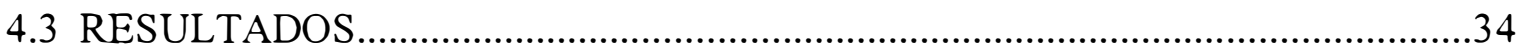

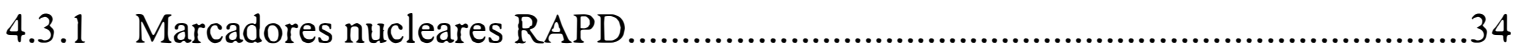

4.3.2 Polimorfismo de sequências de cpDNA...............................................................

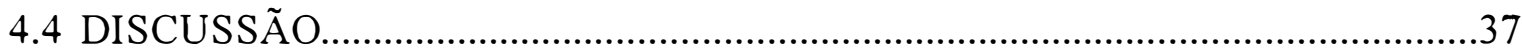

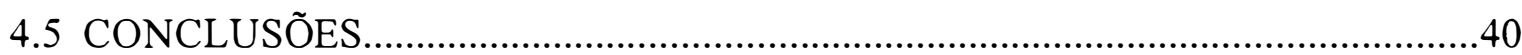

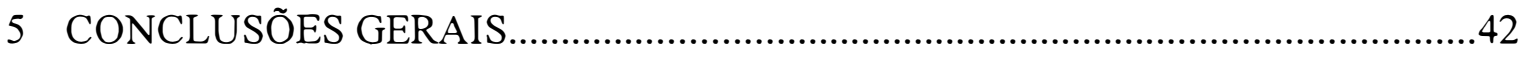

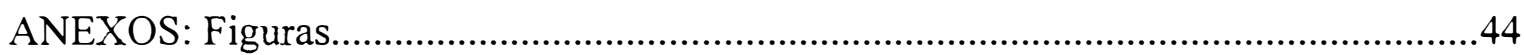

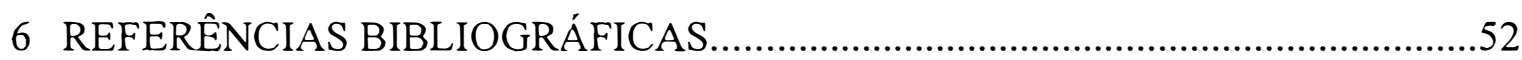




\title{
DISTRIBUIÇÃO DA VARIABILIDADE GENÉTICA EM AROEIRA (Myracrodruon urundeuva - Anacardiaceae) POR MARCADORES RAPD E POLIMORFISMO DE SEQUÊNCIA DE cpDNA.
}

\author{
Autora: ALESSANDRA MARIA MOREIRA REIS \\ Orientador: Dr. DARIO GRATTAPAGLIA
}

\section{RESUMO}

Marcadores RAPD e sequenciamento de cpDNA foram utilizados para estudar a distribuição da variabilidade genética em um banco de germoplasma de aroeira (Myracrodruon urundeuva - Anacardiaceae) e para investigar as contribuições da dispersão de pólen e semente no intercâmbio genético entre populações desta espécie em uma escala regional. O banco de germoplasma é .constituído de acessos de sementes coletadas na área de ocorrência da espécie no Cerrado. Sementes de duas populações naturais foram incluídas na análise, totalizando 192 indivíduos. Uma Análise de Coordenadas Principais baseada na similaridade genética estimada com 83 marcadores RAPD mostrou que não existem agrupamentos definidos entre indivíduos por áreas de coleta. O teste de correlação de matrizes de Mantel revelou uma pequena, porém significativa correlação entre a distância genética e a distância geográfica $(r=0,17$; $\mathrm{p}<0,001$ ). Uma Análise de Variância Molecular (AMOVA) mostrou que $92 \%$ da variabilidade genética estão contidos dentro de zonas de coleta e, embora significativos, somente $3,5 \%$ e $4,5 \%$ da variabilidade são encontrados entre regiões e entre zonas de coleta dentro de regiões, respectivamente. A AMOVA das duas populações resultou em um padrão de distribuição semelhante ao das zonas de coleta, com $97 \%$ da variabilidade dentro de populações. Uma análise de 10 famílias com 16 meio-irmãos revelou que entre 
75 e $89 \%$ da variabilidade estão contidos dentro de famílias, sugerindo que as sementes de uma mesma árvore representam uma porção significativa da variabilidade encontrada na população. Para investigar a contribuição do pólen e da semente na distribuição da variabilidade genética, a variação para marcadores nucleares RAPD foi comparada ao polimorfismo em uma sequência não codificadora do cpDNA. Trinta e nove indivíduos de 5 populações amostrados no banco de germoplasma foram usados nesta parte do estudo. A maior parte da variabilidade genética para DNA nuclear foi encontrada dentro de populações (82\%). Em contraste, uma forte estrutura geográfica foi encontrada entre populações para a sequência de cpDNA analisada. A diferenciação das populações pelo cpDNA foi baseada na presença de uma inserção/deleção de 6 pares de bases encontrada pelo sequenciamento dos indivíduos das 5 populações e, em seguida, visualizada como polimorfismo de comprimento regionalmente estruturado em todos os 192 indivíduos. Os resultados demonstram que polimorfismos intraespecíficos no cpDNA podem ser encontrados facilmente e constituem, como no caso da aroeira, marcadores bastante úteis na identificação regional de acessos de germoplasma. A limitada diferenciação entre populações para marcadores nucleares contrastando com a forte estruturação para o DNA de cloroplasto, sugere uma contribuição significativamente maior da polinização na redução da diferenciação genética entre as populações de aroeira. Tomados conjuntamente, os resultados indicam que, tanto para o estabelecimento de reservas genéticas in situ ou coletas para a conservação ex situ, os esforços devem ser direcionados para a coleta ou conservação de um maior número de indivíduos em um número reduzido de áreas distantes entre si. Caso hajam recursos disponíveis para aumentar a base genética de uma coleção de germoplasma existente, as expedições de coleta devem priorizar populações localizadas a distâncias significativas daquelas já amostradas. 


\title{
DISTRIBUTION OF GENETIC VARIABILITY IN AROEIRA (Myracrodruon urundeuva - Anacardiaceae) FOR RAPD MARKERS AND cpDNA SEQUENCE POLIMORPHISM.
}

\author{
Author: ALESSANDRA MARIA MOREIRA REIS \\ Adviser: Dr. DARIO GRATTAPAGLIA
}

\section{SUMMARY}

RAPD markers and cpDNA sequencing were used to study the distribution of genetic variability in a germplasm collection of Aroeira (Myracrodruon urundeuva) and to investigate the comparative contributions of seed and pollen dispersion in genetic exchange among populations of this species at a regional scale. The germplasm collection is composed of seed accessions collected throughout aroeira's geographical range. Seeds from two natural populations were also included in the study. A Principal Coordinate Analysis (PCO) based on genetic similarities estimated with 83 RAPD markers showed no defined clustering among individuals from the same collection sites. However, a matrix correlation test showed low, but significant correlation between genetic and geographic distances $(r=0.17 ; \mathrm{p}<0.001)$. An AMOVA showed that $92 \%$ of the genetic variation is found within collection sites. Significant variation was found both between regions and between sites within regions, although only 3.54 and $4.44 \%$ of the variation were found at these levels respectively. An AMOVA on the individuals from the two natural populations resulted in a pattern of distribution congruent to the one found for the collection sites, with $97 \%$ of variability within populations. An analysis of 10 open-pollinated families revealed that between $75 \%$ and $89 \%$ of the variability are contained within families, suggesting that seeds from one tree represent a 
significant proportion of the variability found in the population. To investigate the contribution of pollen and seed flow in genetic variability distribution, variation in a biparentally inherited nuclear DNA marker (RAPD) was compared to sequence polymorphism in a noncoding region of the maternally inherited cpDNA. A total of 39 individuals from five populations sampled from the germplasm collection were used in this part of the study. Most of the genetic variability (82\%) for nuclear markers in aroeira is contained within populations. In contrast, a significant differentiation and strong geographical structuring was found among populations for the chloroplast DNA sequence examined. This population differentiation for cpDNA was based on an insertion/deletion polymorphism of a six basepairs sequence that was found from sequencing and was then resolved as a length polymorphism regionally structured in all 192 individuals. The results showed that intraspecific polymorphisms can be readily found in cpDNA and can represent, as in the case of Aroeira, an extremely useful genetic marker in the regional identification of accessions. The limited differentiation among populations for nuclear markers contrasting with the high differentiation for cpDNA strongly suggests a significantly larger contribution of pollination in the genetic exchange among Aroeira populations. Taken jointly, results indicate that, either for the establishment of in situ genetic reserves or for ex situ conservation of Aroeira, efforts should be directed to collection or conservation of a large number of individuals on a reduced number of distant sites. In addition, if resources are available to enlarge the genetic base of the existing collection, expeditions should prioritize populations located in areas at significant distances to those already sampled. 


\section{INTRODUÇÃO}

A necessidade de conservação das espécies florestais nativas da região tropical é evidente e indiscutível. Enquanto muitas espécies estão em risco de extinção na região temperada, várias espécies desaparecem todos os dias nos trópicos (Bawa \& Ashton, 1991). No entanto, a conservação eficiente de uma espécie pressupõe o conhecimento dos parâmetros biológicos e genéticos que determinam a sua diversidade. A estrutura genética de populações determina a sua capacidade de resposta à seleção e é fundamental na formulação de estratégias para a coleta e conservação da biodiversidade de uma espécie. A forma como será feita a amostragem, visando a obtenção da máxima diversidade genética de uma espécie, depende primeiramente do conhecimento da distribuição da variabilidade genética entre e dentro das suas populações.

$\mathrm{O}$ rápido desenvolvimento das técnicas moleculares que permitem o acesso a informações a respeito da dinâmica das populações resultou em avanços consideráveis no entendimento dos processos que envolvem a determinação da estrutura genética das populações. As técnicas baseadas na PCR (Polymerase Chain Reaction) utilizam a amplificação a partir de uma sequência de DNA para obter grandes quantidades do DNA de interesse. Um destes métodos é o RAPD (Random Amplified Polymorphic DNA; Williams et al., 1990), que amplifica ao acaso fragmentos de DNA de diversos tamanhos, gerando assim grande quantidade de polimorfismos e possibilitando uma amostragem extensiva do genoma. Este marcador molecular tem se mostrado bastante eficiente na detecção da variabilidade genética de várias espécies (Nesbitt et al., 1995; Maguire \& Sedgley, 1997).

O estudo do DNA de organelas citoplasmáticas como o cloroplasto (cpDNA) tem sido comumente utilizado pelos biologistas devido ao seu alto grau de conservação e 
herança geralmente uniparental (Parker et al., 1998). Marcadores de cpDNA podem ser obtidos através da digestão do genoma total de cloroplasto utilizando enzimas de restrição (Banks \& Birky, 1985) ou pela amplificação de regiões específicas do DNA e detecção de polimorfismo de comprimento nas sequências através de restrição ou sequenciamento direto do fragmento (McCauley, 1994; Maguire et al., 1996). Embora seu uso seja mais comum no estudo de variabilidade nos níveis taxonômicos mais altos, ultimamente tem-se detectado polimorfismo suficiente para justificar a utilização do cpDNA no estudo da variabilidade genética intraespecífica (Harris \& Ingran, 1991). Nas angiospermas o cpDNA é geralmente herdado maternalmente e, portanto, mede o fluxo gênico realizado pela dispersão das sementes. Já o DNA nuclear tem herança biparental e sua variabilidade é devida ao fluxo gênico via sementes e polinização. Estudos recentes indicam que a análise conjunta de marcadores de DNA nucleares e cpDNA fornece informações importantes a respeito da contribuição da dispersão das sementes e do pólen na organização da variabilidade genética de populações (McCauley, 1995; Powell et al., 1995 a, b).

No Brasil, as espécies mais ameaçadas são aquelas que fornecem recursos madeireiros de alto valor comercial. Dentre as muitas espécies nativas que se encontram em perigo de extinção devido a exploração de madeira está a aroeira (Myracrodruon urundeuva F.F. \& M.F. Allemão.- Anacardiaceae), uma espécie arbórea, dióica, com distribuição geográfica ampla (Santin, 1989).

Este trabalho teve os seguintes objetivos:

1. Quantificar a variabilidade genética mantida em um banco de sementes de aroeira na Empresa Brasileira de Pesquisa Agropecuária (EMBRAPA - Recursos Genéticos e Biotecnologia);

3. Verificar a correlação entre a distância genética e a distância geográfica entre indivíduos desta espécie;

4. Utilizar um marcador de herança biparental (RAPD) e um marcador de herança uniparental (cpDNA) para obter informações a respeito da contribuição da dispersão de sementes e pólen no fluxo gênico e estrutura das populações; 
5. Obter informações que possibilitem determinar rotas de coleta e/ou recoleta de germoplasma para a conservação ex situ, bem como o estabelecimento de reservas genéticas para a conservação in situ.

Os experimentos se basearam nas seguintes hipóteses de trabalho:

1. Seguindo o modelo observado para espécies arbóreas tropicais dióicas, a maior proporção da variabilidade genética para o genoma nuclear em aroeira está contida dentro de populações;

2. Considerando a amplitude da distribuição geográfica da espécie, existe correlação significativa entre a distância geográfica e a distância genética;

3. Por se tratar de um genoma altamente conservado, de baixa taxa evolutiva e de herança exclusivamente maternal, não existe diferenciação genética significativa entre indivíduos da uma mesma população para sequências específicas do genoma de cloroplasto. 


\section{REVISÃO DE LITERATURA}

\subsection{Características gerais da aroeira (Myracrodruon urundeuva F.F \& M.F.}

Allemão)

Myracrodruon urundeuva F.F.\& M. F. Allemão (Syn: Astronium urundeuva (Fr. Allemão) Engler) é uma árvore da família Anacardiaceae (Santin, 1989). Segundo Nogueira et al. (1984), a aroeira é também conhecida por oriundeuva, urundeuva, orindiuva, arendeuva, aroeira-legítima, aroeira-preta, aroeira vermelha, aderno e ubatani. Sua área de ocorrência vai do Ceará até a Argentina e no Brasil é mais frequente no nordeste do país, oeste nos estados da Bahia, Minas Gerais, São Paulo e sul dos estados de Mato Grosso do Sul, Mato Grosso e Goiás. Ocorre desde as formações mais secas e abertas até as muito úmidas e fechadas: caatinga, cerrado e mata pluvial (Rizzini, 1971; Lorenzi, 1992). Nos cerrados é árvore típica de mata caducifolia em solos de origem calcária e com afloramento rochoso (Ribeiro et al., 1983). Parece ser o Brasil o centro de origem dessa espécie e através do Mato Grosso e Mato Grosso do Sul atingiu inicialmente a Bolívia e o Paraguai e em seguida a Argentina (Santin, 1989).

É uma árvore de porte médio a alto, decídua, de fuste reto, galhos relativamente finos e compridos (Santin, 1989). No cerrado e na caatinga atinge de 6 a 14 metros de altura e alcança até 20-25 metros em solos mais férteis da floresta latifoliada semidecídua, com tronco de 50-80 centímetros de diâmetro. A casca é castanho escura, subdividida em placas escamiformes nos troncos mais velhos e cinzenta e escamosa nos exemplares mais jovens. A floração ocorre de novembro a janeiro e a frutificação de setembro a outubro (Rizzini, 1971). Segundo Lorenzi (1992), sua madeira é muito pesada (densidade $1,19 \mathrm{~g} / \mathrm{cm}^{3}$ ), de grande resistência mecânica e 
praticamente imputrecivel, o alburno é diferenciado do cerne e facilmente decomposto. É excelente para obras externas, como postes, moirões, dormentes e armações de pontes; na construção civil, em caibros, vigas, tacos para assoalhos, etc. A árvore, pela beleza de sua copa, aproximadamente piramidal, e por outras qualidades ornamentais, é indicada para a arborização em geral. Seus únicos inconvenientes são a perda das folhas no inverno e provocar irritações em pessoas alérgicas. Ribeiro (1989) cita que a aroeira pode ter uso medicinal, já que é rica em tanino, que tem propriedades adstringentes e favorece a cicatrização das feridas. Por essas características, principalmente a boa qualidade da madeira, a aroeira foi e vem sendo muito explorada, a ponto de ter sua diversidade genética ameaçada. Apesar da citação de Rizzini (1971), Santin (1989) registrou pouquíssima ocorrência da espécie em áreas de mata e levantou a hipótese de que o seu desaparecimento desse ambiente pode ser devido à exploração irracional da sua madeira. A aroeira faz parte da Lista Oficial de Espécies da Flora Brasileira Ameaçadas de Extinção (IBAMA, 1992), se enquadrando na categoria das espécies vulneráveis.

Sabe-se que a polinização da aroeira é entomófila, e que o vento tem participação na dispersão das sementes. Experimentos conduzidos no Distrito Federal por Allen (1991) revelaram que certas árvores de aroeira apresentam flores exclusivamente masculinas, outras produzem flores masculinas dotadas de rudimentos de ovário e ainda outras apresentam somente flores femininas. Porém, o ovário rudimentar não se desenvolve ou, quando se desenvolve um pouco, forma um pequeno fruto abortivo, sem levar à formação de semente viável. Portanto, esse estudo concluiu decisivamente que se trata de uma espécie dióica porque, embora algumas flores sejam estruturalmente monóclinas, elas se comportam funcionalmente como unissexuais masculinas ou femininas. Os estudos desse autor mostraram que o sistema de cruzamento da aroeira é a alogamia, porém indícios não confirmados de agamospermia tornam possível que a taxa de fecundação cruzada não seja de $100 \%$ e a espécie se comporte como apomítica facultativa. A aroeira se reproduz também assexuadamente por rebrotas de raizes e cepas e essa característica é importante na manutenção da espécie em áreas sob intensa ação antrópica (Salomão \& Leite, 1993). A ausência de 
mais dados publicados a respeito da biologia de reprodução dessa espécie evidencia a necessidade de estudos nesse campo.

Testes de progênies e procedências da aroeira, realizados por Nogueira et al. (1986), indicaram a existência de baixa variabilidade genética para características morfométricas entre as progênies e, consequentemente, nas populações de origem do material. Sugerem ainda, através das estimativas de relações entre variância dentro e entre progênies e variância dentro de progênies e variância ambiental, que o sistema reprodutivo da aroeira seja a alogamia.

Os estudos de Moraes (1992) concluíram, com base em métodos quantitativos e análise de sistemas isoenzimáticos, que a variabilidade genética dentro de populações de aroeira é maior do que entre populações. Esse resultado está de acordo com a literatura para espécies tropicais e, segundo Kageyama \& Gandara (1994), isso se deve provavelmente ao fato de ser esta uma espécie secundária rara, com baixa densidade de indivíduos na floresta e fluxo gênico a longa distância. Lacerda (1997) não encontrou estruturação espacial definida nesta espécie e sugere que o fluxo gênico deve ser amplo o bastante para prevenir a formação de estrutura. Moraes (1992) ressalta a necessidade de mais estudos com uma maior amostragem de locos e populações de aroeira.

\subsection{Estrutura genética de populações}

Pode-se definir estrutura genética de uma espécie como sendo o padrão pelo qual a variação genética está distribuída entre e dentro de populações. É resultado da ação conjunta de mutação, migração, seleção e deriva genética (Kageyama, 1990). Segundo Hamrick (1983), fatores importantes na distribuição da variação genética entre e dentro de populações são: tamanho efetivo da população, distribuição geográfica, modo de reprodução e cruzamento, forma de dispersão das sementes e tipo de comunidade onde a espécie é frequente. Para Boyle \& Yeh (1987) o sistema de cruzamento combina-se com as forças evolucionárias (mutação, migração e deriva) para produzir as frequências alélicas e genotípicas nas populações, suas distribuições 
espaciais, tamanhos efetivos, coeficiente de endogamia e fluxo gênico, cada um desses fatores podendo variar entre e dentro de populações e no tempo.

A estrutura populacional de espécies arbóreas florestais é uma consideração importante na conservação de recursos genéticos. Objetivos específicos de conservação genética devem incluir o máximo da variação nos loci gênicos e a manutenção de genes adaptativos específicos. A magnitude relativa da variação dentro, quando comparada com a variação entre populações deve determinar a alocação de esforços para os dois níveis de variação (Boyle \& Yeh, 1987).

O estudo da variação genética em populações naturais geralmente envolvem duas questões básicas. A primeira se preocupa em descrever os níveis de variação genética mantidos dentro de populações ou espécies. A segunda é de particular importância para a conservação dos recursos genéticos, pois está preocupada com o modo como a variação genética está dividida entre e dentro de populações. Isso significa que para que os recursos genéticos sejam manejados, é importante que se entenda como a variância é distribuída e quais as características do ambiente ou da espécie que influenciam esta distribuição (Hamrick, 1983).

Segundo Kageyama \& Gandara (1994) a conservação genética de uma espécie implica no conhecimento da distribuição da variação genética entre e dentro de suas populações, assim como a sua variação no tempo, para que se possa abarcar toda a variabilidade existente no trabalho de conservação.

Existe, no entanto, uma grande carência de informações sobre a diferenciação das populações de espécies arbóreas tropicais. São necessários portanto, estudos e investigações neste campo para se otimizar o manejo e a conservação desse ecossistema (Kageyama, 1987; Bawa, 1992; Kageyama \& Gandara, 1994).

Kageyama \& Dias (1982) citam que os estudos fenotípicos e genotípicos entre e dentro de populações, para diferentes características, são as formas mais apropriadas para se determinar a estrutura genética de uma determinada espécie. Kageyama (1987) propõe que a diversidade genética pode ocorrer a diferentes níveis: a) de espécies dentro de ecossistemas; b) de populações dentro de espécies e c) de indivíduos dentro de 
populações de espécies. A caracterização desses níveis de diversidade é a base para o planejamento das estratégias de conservação genética.

Estudos nas florestas tropicais indicam que a fecundação da grande maioria das espécies arbóreas é cruzada em virtude de auto-incompatibilidade ou dioicismo (Bawa, 1992). Para Allard (1971) o sistema reprodutivo das plantas dióicas emprega o máximo da diversidade genética, constituindo um dispositivo de cruzamento que impede a auto-fecundação, mas não o cruzamento entre parentes, que é uma forma menos pronunciada de endogamia.

Os estudos da estrutura de populações é tradicionalmente realizado através de métodos quantitativos, como os ensaios de procedências e progênies. Porém, este tipo de teste é demorado e caro quando se trata de espécies de ciclo de vida longo, como é o caso das árvores. Ultimamente, os estudos de caracteres morfológicos vêm sendo amparados pelo uso de métodos de análise de marcadores moleculares como a eletroforese de isoenzimas e fragmentos de DNA. Essas técnicas apresentam vantagens entre as quais pode-se citar: são métodos não destrutivos, podem ser aplicadas a qualquer espécie, são relativamente baratas quando se avalia a quantidade de informações fornecida, geram uma grande quantidade de informações em um período reduzido de tempo. (Boyle \& Yeh, 1987; Kageyama, 1990; Hamrick et al., 1991; Ferreira \& Grattapaglia, 1995).

\subsection{Marcadores RAPD (Random Amplified Polymorphic DNA)}

A tecnologia da reação de polimerase em cadeia (PCR - Polymerase Chain Reaction) causou grande revolução na biologia, tanto na pesquisa visando o entendimento de processos biológicos fundamentais, como nas áreas aplicadas envolvendo diagnósticos e melhoramento genético. A PCR é uma técnica poderosa, que envolve a síntese enzimática in vitro de milhões de cópias de um segmento específico de DNA na presença da enzima DNA polimerase. A reação se baseia no anelamento e extensão enzimática de um par de oliconucleotídeos iniciadores (primers), que são desenvolvidos sinteticamente de maneira que suas sequências de nucleotídeos sejam 
complementares a sequências específicas que flanqueiam a região alvo. Muitos métodos de clonagem, sequenciamento e análise de polimorfismo de DNA foram acelerados ou desenvolvidos baseando-se no princípio da PCR, entre eles o RAPD (Random Amplified Polymorphic DNA) (Ferreira \& Grattapaglia, 1995).

A técnica RAPD foi desenvolvida por Williams et al. (1990) e se distingue da PCR por utilizar um único primer com sequência arbitrária de nucleotídeos para a amplificação do DNA genômico. O polimorfismo é gerado pela ausência de sequências específicas de nucleotídeos e podem ser visualizados diretamente em géis de eletroforese através de corantes específicos para DNA. A ausência da banda pode resultar de mudanças na sequência sítio de anelamento com o primer, que impede o perfeita associação do primer ou de mudanças que alteram o tamanho ou impedem o sucesso da amplificação do DNA alvo (Waugh \& Powell, 1992).

O RAPD é considerado um marcador "dominante". Um segmento que é homozigoto para a presença da banda não pode ser distinguido de um heterozigoto e a presença do fragmento é dominante em relação à ausência. Ou seja, ao se observar a presença de uma banda no gel, não é possível determinar se ela se originou a partir de uma ou de duas cópias da sequência amplificada. Vários loci podem ser avaliados simultaneamente, mas pouca informação a respeito de cada loco é obtida, uma vez que a técnica RAPD obtém apenas um alelo em cada loco. (Ferreira \& Grattapaglia, 1995; Westman \& Kresovich, 1997).

A desvantagem do caráter dominante dos marcadores RAPD é superada por inúmeras vantagens como: a facilidade de uso, baixo custo, acessibilidade a não especialistas, utilização de pouca quantidade de DNA genômico, a geração de grande quantidade de polimorfismo amostrando grande parte do genoma e a possibilidade de automatização. Estas características fizeram do RAPD uma técnica amplamente utilizada em vários tipos de estudo envolvendo polimorfismo ao nível do DNA (Karp et al. 1997).

O RAPD tem sido muito utilizado para estudar a variação entre e dentro de espécies de planta, na identificação de acessos e cultivares em bancos genéticos e na construção de mapas genéticos (Tingey \& del Tufo, 1993; Grattapaglia \& Sederoff, 
1994; Caetano-Anollés, 1996). A técnica é eficiente na resolução de vários níveis de polimorfismo inter e intraespecífico, facilitando o acesso de relações genéticas, definição de agrupamentos regionais e a identificação de indivíduos (M'Ribu \& Hilu, 1996). Powell et al. (1995a) citam que técnicas moleculares baseadas em PCR, como o RAPD tem grande potencial para facilitar a conservação e utilização de recursos genéticos vegetais, já que alcançam a melhor estimativa da diversidade genética porque são independentes dos efeitos dos fatores ambientais. Andersen \& Fairbanks (1990) sugerem que estes marcadores moleculares são uma importante ferramenta na caracterização de recursos genéticos vegetais, avaliando um grande número de amostras em pouco tempo e a baixo custo.

\subsection{Análise de cpDNA (DNA de cloroplasto)}

O genoma do cloroplasto das plantas terrestres é um cromossomo circular variando de $120 \mathrm{a} 217 \mathrm{~Kb}$. Sua estrutura é caracterizada pela presença de uma região de repetição invertida. Basicamente o DNA de cloroplasto (cpDNA) é formado por quatro segmentos: duas sequências idênticas de $25 \mathrm{~kb}$ posicionadas como uma duplicação invertida que separa o restante do genoma em uma região curta de cópia única (18kb) uma longa região de cópia única (87kb). (Palmer, 1985, 1987, Olmstead \& Palmer, 1994).

Mudanças na complexidade e estrutura do genoma ocorrem geralmente por mutações de comprimento, pela adição de novas sequências ou a deleção de sequências existentes. A grande maioria dessas mutações são extremamente pequenas, envolvendo de 1-10 pares de base localizados na região não codificadora. Embora mais raras, mutações envolvendo sequências mais longas (de 50 a 1200 pb) também são observadas. Substituições de nucleotídeos são raras (Bowman et al., 1983; Zurawski et al., 1984; Palmer, 1987).

Apesar da existência de alguns casos de herança biparental, na maioria dos casos o cloroplasto tem herança uniparental. É mais comum que o cloroplasto seja herdado da mãe, no caso das angiospermas, ou do pai, na gimnospermas (Sears, 1980). 
A ausência de recombinação na molécula durante a meiose faz com que ela seja herdada clonalmente, a não ser devido a mutações (Palmer, 1987). Consequentemente, o cpDNA contém muita informação histórica e é um excelente marcador para estudos em evolução.

A taxa de evolução no cpDNA é muito lenta. Esta molécula varia pouco no comprimento e o acúmulo de substituições de bases é muito lento (Palmer, 1987). De acordo com Clegg \& Zurawski (1992) a evolução do cpDNA é em média cinco vezes mais lenta do que a do DNA nuclear. Portanto, existe um alto grau de conservação nesta molécula e qualquer mudança tem implicações significativas na filogenia.

Estas características aliadas à presença abundante em células da folha, a facilidade de isolamento e seu tamanho pequeno, fizeram do cpDNA uma molécula muito utilizada em estudos de sistemática. No entanto, devido principalmente ao seu alto grau de conservação, acreditava-se que o polimorfismo detectado no cpDNA não seria suficiente a níveis taxonômicos mais baixos, como o intraespecífico (Palmer, 1985). Mas estudos recentes comprovaram que a variação dentro de uma mesma espécie é maior do que se imaginava e pode ser usada em estudos populacionais (Harris \& Ingran, 1991, Comes \& Abbott, 1998). Segundo Soltis et al. (1992) a variação dentro de espécies não é ao acaso e reflete a distribuição geográfica.

McCauley (1994) cita que apesar do potencial do cpDNA para estudos genéticos em populações, poucos trabalhos são observados nesta área. Existe alguma literatura mostrando que a variação intraespecífica no cpDNA pode ser detectada em um grande número de espécies e que esta variação geralmente apresenta estruturação espacial. Este mesmo autor defende a idéia da utilização do cpDNA para estudos de fluxo gênico. Por ser herdado maternalmente, o cpDNA pode ser disperso através das sementes, mas não pelo pólen. Informações importantes podem ser obtidas ao se combinar o estudo desta organela com um marcador nuclear, que tem herança biparental e portanto carrega informações a respeito da dispersão tanto do pólen como da semente (McCauley, 1995). Comparando as medidas de $\mathrm{F}_{\mathrm{ST}}$ obtido em análises de cpDNA e isoenzimas, foi possível determinar a contribuição do pólen e da semente no fluxo gênico de populações de Silene alba (McCauley, 1994). 
A análise de polimorfismos de cpDNA é tipicamente feita com base em RFLP's (Restriction Fragment Lenght Polymorphisms) que podem ser obtidos através de hibridização com sondas específicas (fragmentos altamente conservados de cpDNA) ou pela visualização direta de fragmentos de restrição. Alternativamente, podem ser analisados RFLP's em fragmentos específicos da molécula amplificados via PCR. Taberlet et al. (1991) desenvolveram primers para a utilização da PCR em cpDNA. Os primers foram desenhados para reconhecer regiões altamente conservadas do gene tRNA, amplificando regiões não codificadoras mais variáveis do cpDNA de várias espécies. Desta forma a amplificação e sequenciamento direto dessas regiões aumentam o poder de resolução de polimorfismo do cpDNA, já que podem ser detectados polimorfismos ao nível de sequência do DNA. Esta técnica aumentou a possibilidade de identificação de marcadores intraespecíficos.

Atualmente, a tendência na análise de variação de cpDNA é a utilização de marcadores microssatélites. A ocorrência de polimorfismo de comprimento na sequência de repetições de mononucleotídeos no genoma do cloroplasto foi reportada e primers flanqueando essas regiões foram desenvolvidos (Powell et al., 1995b). O polimorfismo intraespecífico causado pela variação no comprimento dos microssatélites de cloroplasto são uma ferramenta poderosa no estudo da contribuição relativa do movimento do pólen e da semente no fluxo gênico e estrutura genética das populações de plantas (Powell et al., 1995c). 


\section{VARIABILIDADE GENÉTICA DE MARCADORES RAPD EM UM BANCO DE GERMOPLASMA DE AROEIRA (Myracrodruon urundeuva - Anacardiaceae): RECOMENDAÇÕES PARA CONSERVAÇÃO}

\section{RESUMO}

Marcadores RAPD foram utilizados para estudar a distribuição da variabilidade genética em um banco de germoplasma de aroeira constituído de acessos de sementes coletadas na área de ocorrência da espécie no Cerrado brasileiro. Sementes de duas populações naturais foram também incluídas na análise, totalizando 192 indivíduos. Uma Análise de Coordenadas Principais baseada na similaridade genética estimada com 83 marcadores RAPD mostrou que não existem agrupamentos definidos entre indivíduos por áreas de coleta. O teste de correlação de matrizes de Mantel revelou uma pequena porém significativa correlação entre a distância genética e a distância geográfica $(r=0,17 ; p<0,001)$. Uma Análise de Variância Molecular (AMOVA) mostrou que $92 \%$ da variabilidade genética estão contidos dentro de zonas de coleta e, embora significativos, somente $3,5 \%$ e $4,5 \%$ da variabilidade genética são encontrados entre regiões e entre zonas de coleta dentro de regiões, respectivamente. A AMOVA dos indivíduos das duas populações resultou em um padrão de distribuição semelhante ao encontrado para as zonas de coleta, com $97 \%$ da variabilidade dentro de populações. Uma análise de 10 famílias com 16 meio-irmãos revelou que entre 75 e $89 \%$ da variabilidade está contida dentro de famílias, sugerindo que as sementes de uma mesma árvore, i.e. um acesso, representam uma porção significativa da variabilidade encontrada na população. Os resultados deste trabalho indicam que, tanto para o estabelecimento de reservas genéticas ou coletas para a conservação ex situ, os esforços 
devem ser direcionados para a coleta ou conservação de um maior número de indivíduos por zonas de coleta e o estabelecimento e manejo de reservas genéticas in situ podem visar um número reduzido de áreas distantes entre si. Caso hajam recursos disponíveis para aumentar a base genética da coleção existente, as expedições de coleta devem priorizar populações localizadas a distâncias significativas daquelas já amostradas.

\section{RAPD VARIATION IN A GERMPLASM COLLECTION OF AROEIRA (Myracrodruon urundeuva - Anacardiaceae): RECOMMENDATIONS FOR CONSERVATION.}

\section{SUMMARY}

RAPD markers were used to investigate the distribution of genetic variability in a germplasm collection of the dioecious tropical tree Aroeira (Myracrodruon urundeuva) composed of seed accessions collected throughout its geographical range. Seeds from two natural populations were also included in the study. A Principal Coordinate Analysis (PCO) based on genetic similarities estimated with 83 RAPD markers showed no defined clustering among individuals from the same collection sites. However, a matrix correlation test showed low, but significant correlation between genetic and geographic distances $(r=0.17 ; p<0.001)$. An AMOVA showed that $92 \%$ of the genetic variation is found within collection sites. Significant variation was found both between regions and between sites within regions although only 3.54 and $4.44 \%$ of the variation were found at these levels respectively. An AMOVA on the individuals from the two natural populations resulted in a pattern of distribution congruent to the one found for the collection sites, with $97 \%$ of variability within populations. An analysis of 10 open-pollinated families revealed that between $75 \%$ and $89 \%$ of the variability are contained within families, suggesting that seeds from one tree (i. e. an accession) represent a significant proportion of the variability found in the population. These results indicate that, either for the establishment of in situ genetic reserves or for 
ex situ conservation, efforts should be directed to collection or conservation of a large number of individuals per site. Furthermore, the establishment and long term management of in situ genetic reserves could focus on a reduced number of distant sites. In addition, if resources are available to enlarge the genetic base of the existing collection, expeditions should prioritize populations located in areas at significant distances to those already sampled.

\subsection{INTRODUÇÃO}

A aroeira (Myracrodruon urundeuva F.F. \& M.F. Allemão. Syn: Astroniun urundeuva (Fr. All.) Engler) é uma árvore da família Anacardiaceae que ocorre naturalmente do Ceará até a Argentina. No Brasil é mais frequente no nordeste do país e nos estados de Minas Gerais, São Paulo, Goiás, Mato Grosso e Mato Grosso do Sul, podendo ser encontrada desde as formações mais secas e abertas, como o cerrado e a caatinga, até em matas pluviais (Rizzini, 1971; Santin, 1989; Lorenzi, 1992). Sua madeira possui alta densidade (até $1,2 \mathrm{~g} / \mathrm{cm}^{3}$ ) e é bastante resistente ao apodrecimento, o que a torna uma espécie muito explorada para fins de construção civil e obras externas. A exploração intensiva levou a aroeira a ser incluída na lista oficial das espécies ameaçadas de extinção (IBAMA, 1992).

Uma das maiores dificuldades para a conservação e manejo racional das espécies vegetais tropicais é a carência de informações sobre os níveis e a organização da variabilidade genética em populações naturais e bancos de germoplasma, já que a estrutura genética de uma população determina sua capacidade de resposta à seleção, tanto natural quanto artificial (Bawa \& Ashton, 1991). Basicamente, são duas as estratégias de conservação adotadas: (1) Conservação in situ, que visa a proteção do ecossistema, permitindo a contínua evolução das espécies e manutenção da diversidade intra e inter específica de populações, indivíduos e genes; e (2) Conservação ex situ, que 
prioriza o germoplasma, preservando-o e disponibilizando-o para a pesquisa e recuperação de áreas degradadas (FAO, 1989).

É fundamental conhecer a estrutura genética da espécie, a fim de que sua conservação seja de fato eficiente. A amostragem extensiva ao longo de toda a zona de ocorrência da espécie ou a amostragem estratégica em sítios específicos de alta variabilidade genética depende do conhecimento dos padrões de variabilidade genética entre e dentro de populações da espécie (Eriksson et al., 1993). Um banco de germoplasma estabelecido deve ser caracterizado, não só para distinguir acessos ou grupos taxonômicos, mas para economizar espaço e recursos que podem ser utilizados racionalmente quando a composição genética da coleção é conhecida.

A análise do DNA é uma ferramenta poderosa para responder questões relacionadas à distribuição da variabilidade entre e dentro de espécies e populações. Nos últimos anos, várias técnicas baseadas na técnica da PCR (Polymerase Chain Reaction) vêm sendo desenvolvidas e utilizadas para a investigação do polimorfismo ao nível do DNA (Caetano-Anollés; 1996, Karp et al. 1997). A técnica RAPD (Random Amplified Polymorphic DNA; Williams et al., 1990) utiliza um primer de sequência arbitrária para amplificar simultaneamente fragmentos de DNA de diferentes tamanhos e que possuem mobilidade diferente em um gel de eletroforese. A simplicidade, acessibilidade, baixo custo, ampla disponibilidade de primers e sua transferibilidade entre espécies são características que tornaram o RAPD uma técnica muito utilizada na investigação de diversidade genética, tanto em estudos de populações (Yeh et al., 1995) quanto na caracterização de recursos genéticos (Ford-Lloyd et al., 1997). Em espécies florestais, em que estudos morfológicos demandam longos períodos de tempo e grandes áreas experimentais, o uso de marcadores moleculares vem sendo particularmente útil (Nesbitt et al.,1995; Rossetto et al., 1995).

Os objetivos deste trabalho foram: 1. Quantificar a variabilidade genética existente entre e dentro de diferentes níveis hierárquicos atualmente mantida na coleção de sementes de aroeira em um banco de germoplasma; 2. Verificar a correlação entre a distância genética e a distancia geográfica entre indivíduos de aroeira; 3. Obter 
diretrizes para o estabelecimento de novas rotas de coleta visando o enriquecimento da variabilidade genética do banco.

\subsection{MATERIAL E MÉTODOS}

3.2.1 Material vegetal. Sementes de aroeira armazenadas no banco de germoplasma da EMBRAPA - Recursos Genéticos e Biotecnologia foram obtidas em expedições de coleta em diversos pontos dos Estados de Minas Gerais, Bahia, Goiás e Piauí nos anos de 1987, 1988, 1989 e 1995. Sementes de cada árvore são consideradas famílias de meio-irmãos de polinização aberta e constituem um acesso da coleção. Dos 192 indivíduos incluídos neste estudo, 159 pertencem à essa coleção e 33 são procedentes de sementes obtidas em 2 populações naturais: 20 indivíduos de uma população localizada em Paulo de Faria (SP) e 13 indivíduos localizados em Selvíria (MS) (Figura 1). Para o estudo da variabilidade entre e dentro de famílias, duas famílias com 16 indivíduos cada uma foram amostradas em cinco localidades diferentes. Sementes de cada acesso foram plantadas em casa de vegetação e monitoradas até a obtenção de mudas com folhas expandidas (3-4 meses). Foram colhidas folhas de 1 indivíduo de cada família, no caso do estudo de populações e de 16 indivíduos por família para o estudo das famílias. Cada indivíduo analisado representou um acesso que por sua vez corresponde a uma família de meio-irmãos. O indivíduo analisado contém portanto, metade do genoma da árvore mãe e a outra metade é proveniente de alguma outra árvore doadora de pólen.

3.2.2 Extração do DNA e reações RAPD. O DNA foi extraído de cerca de $150 \mathrm{mg}$ de tecido foliar fresco seguindo-se o protocolo descrito por Doyle \& Doyle (1990) e quantificado em gel de agarose $0,8 \%$ corado com brometo de etídeo. Oito amostras de DNA foram utilizadas para se fazer uma triagem de 165 oligonucleotídeos iniciadores "primers" (Operon Technologies). Vinte e sete primers que amplificaram marcadores RAPD de boa resolução e polimorfismo foram selecionados e utilizados para a análise 
RAPD. Os 192 indivíduos foram divididos em quatro lotes de 48 amostras selecionadas aleatoriamente, a fim de aumentar a robustez dos dados gerados (Grattapaglia \& Sederoff, 1994). Os quatro lotes de amostras foram analisados em ensaios independentes e somente aqueles marcadores polimórficos com boa reproducibilidade em todos os lotes foram selecionados. O mesmo critério foi utilizado no estudo das familias, onde foram utilizados 12 primers para obter 50 marcadores

3.2.3 Análise dos dados. Os marcadores RAPD tem natureza dominante e foram portanto interpretados de forma binária. Os dados foram registrados diretamente em planilha considerando presença ou ausência de bandas. O programa NTSYS 2.0 (Rohlf, 1997) foi utilizado para gerar uma matriz de similaridade genética utilizando o coeficiente de Dice (1945) que não leva em consideração a dupla ausência de bandas no cômputo de similaridade. Este coeficiente é análogo ao de Nei \& Li (1979), e é calculado pela expressão $2 \mathrm{a} / 2 \mathrm{a}+\mathrm{b}+\mathrm{c}$ (onde: $\mathrm{a}=$ número de bandas presentes nos dois indivíduos comparados; $\mathrm{b}=$ número de bandas presentes no indivíduo 1 e ausentes no indivíduo 2; e c = número de bandas ausentes no indivíduo 1 e presentes no indivíduo 2). Um teste de significância da correlação entre a matriz de similaridade genética obtida e uma matriz de distância geográfica em quilômetros entre os 192 indivíduos foi realizado pelo teste de correlação entre matrizes de Mantel (1967). Ainda a partir da matriz de similaridade foi feita uma Análise de Coordenadas Principais (PCO) a fim de verificar possíveis agrupamentos dos indivíduos por similaridade genética. Uma análise semelhante foi feita com os dados obtidos para as 10 famílias de 16 indivíduos.

O programa Arlequin 1.1 (Schneider et al., 1997) foi utilizado para quantificar as proporções de variância molecular entre e dentro dos pontos de coleta em diferentes delineamentos. Para esta análise estatística, os indivíduos do banco de germoplasma foram agrupados em 9 zonas de coleta de acordo com a proximidade geográfica entre as árvores. A distância entre indivíduos dentro de cada zona de coleta variou de 300 metros a 100 quilômetros. Dezesseis indivíduos isolados não se inserem em nenhuma das zonas de coleta e não foram incluídos nesta análise, que totalizou portanto 143 amostras. Uma matriz de distância Euclidiana (Huff et al., 1993) foi construída e a partir desta foi 
realizada uma Análise de Variância Molecular (AMOVA, Excoffier et al., 1992) decompondo os componentes da variância nos seguintes níveis: entre regiões (direita e esquerda do rio São Francisco) entre zonas de coleta dentro de regiões e dentro de zonas de coleta. Treze indivíduos de Selvíria (MS) e vinte de Paulo de Faria (SP) foram efetivamente coletados a distâncias que permitem o contato reprodutivo imediato e foram assim analisadas como populações propriamente ditas. Uma análise separada estimou os componentes da variância entre localidades, entre famílias dentro de localidades e dentro de famílias. A significância dos componentes de variação foi testada por 1000 permutações entre e dentro dos níveis hierárquicos.

\subsection{RESULTADOS}

3.3.1 Marcadores RAPD. O procedimento de extração de DNA utilizado permitiu a obtenção de DNA genômico total em quantidade e qualidade ideais para a geração de marcadores RAPD (Figura 2). Após a triagem de 165 "primers", foram selecionados os seguintes 27: OPA20, OPG14, OPJ9, OPJ10, OPJ11, OPJ16, OPK16, OPL1, OPL5, OPL8, OPL12, OPL17, OPL18, OPN4, OPN6, OPR3, OPR15, OPW6, OPW19, OPX6, OPX8, OPY2, OPY3, OPY7, OPY13, OPZ18 e OPZ19. No primeiro lote de 48 indivíduos foram identificados 101 marcadores polimórficos de fácil interpretação, ou seja 3,74 marcadores/primer. No entanto, ao final das quatro replicações com 48 indivíduos cada, somente 83 marcadores RAPD apresentavam bandas polimórficas definidas e perfeitamente reproduzíveis nos 192 indivíduos. Somente estes 83 marcadores foram considerados nas análises.

3.3.2 Análise de similaridade genética. Um agrupamento feito por UPGMA (Unweighted Pair Group with Arithmetic Mean) a partir da matriz de coeficientes de similaridade de Dice mostrou que a similaridade genética entre os todos os indivíduos das zonas de coleta representadas no banco de germoplasma variou de 54 a $86 \%$. Esta 
similaridade foi mais alta entre os indivíduos das duas populações, variando de 67 a $85 \%$. Foi verificada uma diferenciação clara dos indivíduos das populações de Paulo de Faria (SP) e Selvíria (MS) em relação aos indivíduos pertencentes ao banco de germoplasma. Estes resultados foram visualizados em uma Análise de Coordenadas Principais incluindo todos os 192 indivíduos (Figura 3a). A dispersão de pontos revela a separação dos 33 indivíduos das populações de Selvíria e Paulo de Faria e demonstra que não existe um padrão definido de agrupamento por estrutura populacional, tanto entre os indivíduos do banco de germoplasma, como das duas populações. O mesmo resultado foi observado na análise de similaridade genética dos indivíduos organizados em famílias de meio-irmãos (Figura 3b). A variação em similaridade genética dentro de famílias é tão ampla quanto entre famílias, e consequentemente não ocorre um agrupamento de indivíduos pertencentes à mesma família. Também nesta análise foi verificada a separação clara das duas famílias procedentes de Paulo de Faria.

Foi estimada uma correlação $r$ igual a $-0,17$ entre as matrizes de distância geográfica e similaridade genética. Este valor é significativo ao nível de $0,1 \%$ (teste com 1000 permutações), indicando que uma pequena fração da distância genética entre os 192 indivíduos pode ser explicada pela distância geográfica existente entre eles.

3.3.3 Análises de variância molecular. Tendo em vista a diferenciação clara das populações de São Paulo e Mato Grosso do Sul dos demais pontos de coleta, as Análises de Variância Molecular (AMOVAs) foram realizadas separadamente para os 159 indivíduos do Banco de Germoplasma e os 33 das duas populações. As zonas de coleta foram agrupadas em duas regiões considerando o principal acidente geográfico na área de ocorrência da espécie, ou seja, à direita e à esquerda do rio São Francisco. Os resultados desta análise demonstraram que a maior parte da variabilidade genética (92\%) estimada com marcadores RAPD ocorre entre indivíduos dentro das zonas de coleta (Tabela 1a). Uma porção significativamente menor da variabilidade é encontrada entre zonas de coleta e entre regiões, 4,4\%, e 3,54\% respectivamente. Entretanto, embora pequenos, ambos os componentes desta variabilidade são significativos. 
A AMOVA entre e dentro das populações de Selvíria (MS) e Paulo de Faria (SP) também revelou que uma maior proporção da variabilidade genética está contida dentro das populações $(97,1 \%)$. A variabilidade entre populações $(2,9 \%)$ foi significativa ao nivel de 0,05 (Tabela $1 \mathrm{~b}$ ).

Tabela 1. AMOVA dos dados de marcadores RAPD dos indivíduos de aroeira (Myracrodruon urundeuva) em (a) nove zonas de coleta separadas em duas regiões e (b) duas populações

\begin{tabular}{lccccc}
\hline \multicolumn{1}{c}{ Fonte de Variação } & G.L & S.Q. & Comp. Var. & \% Total & $p^{(7)}$ \\
\hline a. Entre Regiões. & 1 & 59,41 & 0,50 & 3,54 & 0,0097 \\
$\begin{array}{l}\text { Entre Zonas de Coleta } \\
\text { dentro de Regiões. }\end{array}$ & 7 & 157,71 & 0,62 & 4,44 & $<0,001$ \\
$\begin{array}{l}\text { Dentro de Zonas de } \\
\text { Coleta. }\end{array}$ & 134 & 1740,82 & 12,99 & 92,01 & \\
\hline$\quad$ Total & 142 & 1957,93 & 14,12 & & \\
\hline b. Entre Populações. & 1 & 16,91 & 0,34 & 2,90 & 0,0215 \\
$\quad \begin{array}{l}\text { Dentro de } \\
\text { Populações }\end{array}$ & 31 & 356,63 & 11,50 & 97,10 & \\
\hline$\quad$ Total & 32 & 373,54 & 11,85 & & \\
\hline
\end{tabular}

(1) Probabilidade de o valor estimado do componente de variação ser ao acaso. Teste realizado por 1000 permutações.

A análise de variabilidade entre e dentro famílias de meio-irmãos coletadas e mantidas na EMBRAPA indica que a proporção de variabilidade existente entre os indivíduos de uma mesma família é de $74,5 \%$ (Tabela $2 a$ ). O restante da variabilidade está distribuída predominantemente entre árvores de uma mesma zona de coleta $(20,36 \%)$ e apenas $5,18 \%$ entre zonas de coleta. Um comportamento semelhante de distribuição de variabilidade foi observado ao analisar indivíduos de duas famílias de meio-irmãos da população de Paulo de Faria (Tabela 2b) 
Tabela 2. AMOVA de famílias de aroeira (Myracrodruon urundeuva) obtidas em (a) 4 zonas de coleta da EMBRAPA e em (b) 1 população localizada em Paulo de Faria (SP).

\begin{tabular}{lccccc}
\hline \multicolumn{1}{c}{ Fonte de Variação } & G.L & S.Q. & Comp. Var. & $\%$. Total & $p^{(1)}$ \\
\hline a. Entre zonas de coleta. & 3 & 141,36 & 0,43 & 5,18 & 0,0205 \\
$\begin{array}{l}\text { Entre Famílias } \\
\text { dentro de Locais. }\end{array}$ & 4 & 133,31 & 1,69 & 20,36 & $<0,001$ \\
$\quad$ Dentro de Famílias. & 120 & 744,19 & 6,20 & 74,47 & \\
\hline$\quad$ Total & 127 & 1018,86 & 8,33 & & \\
\hline $\begin{array}{l}\text { b. } \text { Entre Famílias. } \\
\quad \text { Dentro de Famílias. }\end{array}$ & 1 & 19,31 & 0,81 & 11,22 & $<0,001$ \\
\hline$\quad$ Total & 31 & 191,69 & 6,39 & 88,78 & \\
\hline
\end{tabular}

(1) Probabilidade de o valor estimado do componente de variação ser ao acaso. Teste realizado por 1000 permutações.

\subsection{DISCUSSÃO}

3.4.1 Análises RAPD em aroeira. A técnica RAPD se mostrou altamente eficiente na geração de dados de variabilidade genética para aroeira. Uma média de quase quatro marcadores por primer selecionado foram obtidos permitindo a estimativa de similaridade genética e discriminação individual. Marcadores RAPD apresentam uma herança dominante e fornecem com isso uma quantidade de informação genética por loco mais limitada do que os marcadores isoenzimáticos, anteriormente utilizados para estudar esta espécie (Moraes, 1992; Lacerda, 1997). Entretanto, este estudo demonstrou ser possível a obtenção de um número significativamente maior de marcadores em menor período de tempo. Utilizando a técnica RAPD amplia-se consideravelmente a cobertura genômica a partir da qual são derivadas as estimativas de variabilidade e evita efeitos de amostragem de locos. O delineamento utilizado para a análise RAPD foi estringente. A análise dos indivíduos em lotes independentes possibilitou obter uma 
estimativa de reproducibilidade dos marcadores moleculares gerados e selecionar aqueles com absoluta repetição de padrão de experimento para experimento. Considerando os 4 experimentos independentes, foi observada uma reproducibilidade de cerca de $83 \%$, ou seja $17 \%$ dos marcadores interpretados no primeiro lote de indivíduos não puderam ser facilmente interpretados nos 3 lotes subsequentes. Este resultado é provavelmente devido a pequenas diferenças de condições específicas do ensaio de PCR em cada bateria de reações RAPD. A reproducibilidade dos marcadores RAPD pode ser afetada por fatores como a concentração do DNA genômico, concentração do primer, concentração do íon magnésio, a qualidade da Taq polimerase e as condições de temperatura do termociclador (Rafalski et al., 1996). Algumas bandas podem apresentar ambiguidade de interpretação devido ainda ao baixo poder de um primer em discriminar sítios de amplificação distintos ou da competição entre diferentes sítios de amplificação por substratos e enzima, de modo que a presença de um segmento pode interferir na amplificação de outros (Ferreira e Grattapaglia, 1995). As reações RAPD utilizando os 27 primers selecionados foram feitas com cada grupo de amostras aleatórias em épocas diferentes e os reagentes utilizados em cada uma das 4 baterias não pertenciam necessariamente a um mesmo lote de fabricação. Os termocicladores utilizados também não foram sempre os mesmos e é sabido que, mesmo quando programados para as mesmas temperaturas, pode haver diferença nos parâmetros de termociclagem entre máquinas. Além disso deve-se considerar as diferenças devidas a erros na pipetagem de volumes pequenos. Desta forma, a seleção das bandas reprodutíveis e claramente interpretáveis garantiu a robustez dos dados gerados, já que os artefatos eventualmente presentes nas reações foram eliminados. Segundo Ellsworth et al. (1993), em estudos de variabilidade genética entre indivíduos utilizando marcadores RAPD, a interpretação de artefatos como marcadores pode super estimar a variabilidade de fato existente.

3.4.2 Similaridade genética. Os resultados demonstraram que existe uma variabilidade genética significativa e que não há agrupamento definido entre os acessos do banco de germoplasma. Apesar de a análise ter sido realizada com um indivíduo por acesso, cada 
acesso é formado por uma família de meio-irmãos. Os resultados da análise das famílias (PCO e AMOVA) mostram que a variabilidade dentro de cada família e portanto, dentro de cada acesso é alta. Essas informações indicam portanto, que o banco de germoplasma de aroeira está mantendo uma ampla variabilidade genética e que não existem acessos geneticamente similares ao ponto de permitir um descarte. Além disso, existe uma diferença significativa entre famílias que justifica plenamente a coleta e manutenção dos acessos por matrizes.

A Análise de Coordenadas Principais indicou ainda que os indivíduos das populações de Paulo de Farias e Selvíria são geneticamente distintos dos indivíduos do banco da EMBRAPA. O fato de os indivíduos destas populações estarem separados dos demais pode ter diversas explicações. Uma possibilidade é a própria questão de amostragem. Enquanto os indivíduos das zonas de coleta foram coletados a distâncias mínimas de 300 metros, os indivíduos das populações foram coletados a distâncias menores. No entanto, esta hipótese não parece ser provável ao se observar que a dispersão dos pontos referentes aos indivíduos das duas populações é tão ampla quanto aquela observada para os indivíduos das zonas de coleta. Embora pequena, a correlação entre a distância genética e a geográfica pelo teste de Mantel foi significativa. Ao estimar esta correlação utilizando apenas dois indivíduos de cinco dos pontos de coleta distribuídos a distâncias de 250 a 1400km entre si, a correlação de Mantel foi de -0,56. Estes resultados tomados conjuntamente, sugerem que a diferenciação entre as duas populações e as zonas de coleta se deve predominantemente a uma questão de distância geográfica. A dispersão das sementes de aroeira é feita pelo vento (Salomão \& Leite, 1993). Segundo Loveless \& Hamrick (1984) este padrão de dispersão diminui a diferenciação local, mas a migração a longas distâncias é limitada.

3.4.3 Distribuição de variabilidade Os resultados das AMOVAs, onde foram efetivamente quantificadas as proporções de variabilidade genética entre e dentro de agrupamentos, corroboram as observações das análises de similaridade genética. A variabilidade existente entre os indivíduos de uma mesma zona de coleta foi significativamente maior do que a variabilidade existente entre diferentes zonas de 
coleta. A análise das familias mostrou que, embora a maior parte da variabilidade esteja contida dentro de familias, a diferença entre elas é significativa. Este resultado está de acordo com o esperado para uma espécie arbórea tropical dióica e, portanto, de hábito alógamo (Kageyama, 1990; Bawa, 1992).

A alogamia, além de aumentar a troca genética dentro das populações, permite fluxo gênico significativo entre as populações, diminuindo assim as divergências entre elas. Moraes (1992) e Lacerda (1997) utilizaram isoenzimas em estudos com populações de aroeira e também encontraram a maior parte variabilidade genética dentro de populações. Os resultados de RAPD para Populus tremuloides uma espécie dióica e de ampla distribuição na América do Norte, indicaram que 97,4\% da variabilidade genética está contida dentro de populações e apenas 2,6\% (significativo ao nível de $1 \%$ de probabilidade) entre as populações (Yeh et al., 1995). Em Campnosperma brevipetiolata, uma Anacardiaceae tropical, somente 17\% da variância genética total foi encontrada entre populações localizadas em ilhas no Pacifico. Novamente a maior parte da variância foi encontrada dentro das populações das ilhas (Sheely \& Meagher, 1996). Vários outros trabalhos com espécies florestais onde a variabilidade genética foi estimada com marcadores isoenzimáticos ou RAPD também relataram resultados em que a maior parte da variância genética foi encontrada dentro de populações (Nesbitt et al., 1995; Rossetto et al., 1995; Maguire \& Sedgley, 1997; Hogbin et al., 1998).

Os resultados da AMOVA mostraram que o acidente geográfico demarcado pelo Rio São Francisco é um fator significativo na estruturação da diferenciação genética entre populações de aroeira (Tabela 1). Entretanto, a proporção de variabilidade explicada por este fator foi baixa $(3,54 \%)$ o que sugere que este rio não impede a ocorrência de fluxo gênico entre populações nas duas margens. É importante lembrar ainda que a largura deste rio varia muito ao longo de sua extensão, em alguns pontos forma represas para usinas hidrelétricas, mas em outros pode ter menos de 50 metros e não impedir o fluxo de pólen, já que Nason \& Hamrick (1997) detectaram fluxo de pólen na Anacardiaceae Spondias mobin (também polinizada por abelhas e insetos pequenos) a distâncias bastante superiores a 100 metros tanto em florestas contínuas como em fragmentadas. 
Para avaliar comparativamente o efeito do rio com o simples efeito de distância geográfica, foram realizadas 20 AMOVAs de combinações diferentes de pares de zonas de coleta. Em 16 análises a diferenciação entre zonas de coleta significativa ao nível de 0,005. Os resultados de algumas destas AMOVAs estão apresentadas na Figura 4. Pode-se notar que nem sempre duas zonas de coleta separadas pelo rio estão mais distantes geneticamente do que duas que estão do mesmo lado. Por exemplo, a diferença entre a zona 4 e a zona 6 (do mesmo lado do rio) é de 5,95\% ( $\mathrm{p} \leq 0,001$ ) enquanto a diferença entre a mesma zona 4 e a zona 3 (separadas pelo rio) é de $4,12 \%(p=0,02)$; a diferença entre as zonas 7 e 4 (do mesmo lado do rio) é de 7,08\% (p $\leq 0,001)$ e entre as zonas 8 e 3 (separadas pelo rio) é de 7,26 ( $\mathrm{p} \leq 0,001)$. Pode-se notar também pela Figura 3 que, geralmente, maiores distâncias geográficas estão aparentemente relacionadas a distâncias genéticas relativamente (não necessariamente estatisticamente) maiores. Em todas as AMOVAs, com exceção daquelas onde as populações de SP e MS foram incluídas, a proporção de variabilidade genética entre zonas de coleta foi menor do que $10 \%$. Estes resultados sugerem portanto, que a distância geográfica entre populações, independentemente da ocorrência de um acidente geográfico entre elas, pode gerar alguma diferenciação genética. Entretanto, esta diferenciação, mesmo entre zonas de coleta a grandes distâncias, é quantitativamente pequena em relação à variabilidade contida dentro de zonas de coleta.

\subsection{CONCLUSÕES}

Além de fornecer informações sobre os padrões de distribuição da variabilidade genética da aroeira na natureza, este estudo valida a representatividade da coleção de germoplasma existente e ajuda a delinear futuras estratégias para a conservação dessa espécie. A análise de similaridade e a partição de variabilidade entre e dentro famílias de meio-irmãos revelam que a polinização é eficiente em promover o fluxo gênico nesta espécie. Entre 75 e 90\% da variabilidade genética é encontrada dentro 
de famílias indicando que a coleta de sementes por árvore garante a amostragem de uma porção significativa da variabilidade existente na população

A análise dos marcadores RAPD revelou que a maior parte da variabilidade genética é encontrada dentro de populações, mesmo a longas distâncias geográficas. Apesar de a amostragem realizada nas expedições de coleta não ter contemplado populações, e sim buscado nas zonas de coleta representantes da espécie em toda sua extensão geográfica no Cerrado, a análise de populações serviu como uma referência experimental para comparar e validar a partição de variabilidade encontrada nas zonas de coleta. Os resultados desta análise genética indicaram que os padrões de similaridade genética e as proporções de variabilidade encontradas entre e dentro das zonas de coleta são congruentes àqueles obtidos para as amostras que efetivamente representam populações. Este resultado indicaque a maior parte da variabilidade genética deverá ser encontrada dentro das populações existentes nas zonas de coleta amostradas no banco de germoplasma, validando assim a representatividade genética da coleção.

Assim sendo, futuras expedições de coleta ou o estabelecimento de reservas genéticas in situ poderão concentrar seus esforços em um número reduzido de áreas de ocorrência da espécie e coletar ou conservar um maior número de indivíduos em uma mesma população mantendo a estruturação por famílias. Entretanto, se houver disponibilidade de recursos para maximizar a manutenção de variabilidade em um banco de germoplasma, deverão ser contempladas populações a distâncias geográficas significativas daquelas previamente amostradas, buscando assim capturar a maior proporção possível da variabilidade existente entre populações. 


\section{DISTRIBUIÇÃO REGIONAL DA VARIABILIDADE EM RAPD E cpDNA DE AROEIRA (Myracrodruon urundeuva - Anacardiaceae)}

\section{RESUMO}

Marcadores RAPD e o sequenciamento de uma região não codificadora do DNA de cloroplasto foram utilizados para analisar, em escala regional, a contribuição da dispersão do pólen e da semente na distribuição da variabilidade genética no cpDNA e DNA nuclear de aroeira (Myracrodruon urundeuva - Anacardiaceae), uma espécie tropical de ampla distribuição geográfica. A maior parte da variabilidade genética para DNA nuclear está dentro de populações (82\%). Em contraste, uma forte estrutura geográfica foi encontrada entre populações para a sequência de cpDNA analisada. A diferenciação das populações pelo cpDNA foi baseada na presença de uma inserção/deleção de 6 pares de bases acompanhada de uma transição C-T encontrada pelo sequenciamento e visualizada como polimorfismo de comprimento em um total de 192 amostrada distribuidas ao longo da área de ocorrência da espécie no Brasil central. Este polimorfismo encontra-se extremamente estruturado geograficamente já que todos os indivíduos localizados mais na zona norte e leste possuem a inserção 5'-GAAAAA-3' enquanto todos os indivíduos localizados mais ao centro e sudoeste não possuem a inserção. Os resultados demonstram que polimorfismos de inserção/deleção no cpDNA podem ser encontrados em estudos intraespecíficos e constituem, como no caso da aroeira, marcadores bastante úteis para identificação em escala regional de acessos para manejo de germoplasma e procedimentos de conservação e utilização. A limitada diferenciação entre populações para marcadores nucleares contrastando com a alta 
diferenciação para o DNA de cloroplasto, sugere uma contribuição significativamente maior da polinização no intercâmbio genético entre populações de aroeira.

\section{REGIONAL DISTRIBUTION OF RAPD AND cPDNA VARIABILITY IN AROEIRA (Myracrodruon urundeuva - Anacardiaceae).}

\section{SUMMARY}

RAPD markers and sequencing of a noncoding region of the chloroplast DNA were used to investigate the comparative contributions of seed and pollen dispersion in the distribution of genetic variability in populations of the dioecious tropical tree Aroeira (Myracrodruon urundeuva) at a regional scale. Most of the genetic variability $(82 \%)$ for nuclear markers in aroeira is contained within populations. In contrast, a significant differentiation and strong geographical structuring was found among populations for the chloroplast DNA sequence examined. This population differentiation for cpDNA was based on a consistent insertion/deletion polymorphism of a six basepairs sequence, accompanied by a C-T transition that was found from sequencing and was then resolved as a length polymorphism in an extended set of 192 individuals covering the entire geographical distribution of the species. This polymorphism defined a clear structuring according to geographical origin as all individuals from the northern and eastern range had the insertion 5'-GAAAAA-3' while all individuals from the central and southwestern populations did not. Our results show that insertion/deletion cpDNA polymorphisms for intraspecific studies can be readily found and can represent, as in the case of Aroeira, an extremely useful genetic marker in the regional identification of aroeira accessions for germplasm management, conservation and utilization procedures. The limited differentiation among populations for nuclear markers contrasting with the high differentiation for cpDNA strongly suggests a significantly larger contribution of pollination in the genetic exchange among populations of aroeira. 


\subsection{INTRODUÇÃO}

A aroeira (Myracrodruon urudeuva, F.F. \& M. F. All.; Anacardiaceae) é uma espécie arbórea economicamente importante, de ampla distribuição geográfica no Brasil, tanto em área de cerrado e caatinga, quanto em matas úmidas (Rizzini, 1971; Santin, 1989). É uma espécie dióica, polinizada por insetos de tamanho pequeno. A dispersão de suas sementes é principalmente anemocórica. Apesar de estar ameaçada pela intensa exploração de sua madeira (IBAMA, 1992), pouco se conhece a respeito da biologia desta espécie e da diversidade genética em sua área de ocorrência.

Informações a respeito dos níveis, organização e dinâmica da variabilidade genética em populações de uma espécie são fundamentais para delinear estratégias eficientes de conservação. No entanto, estudos desta natureza para espécies arbóreas tropicais são relativamente poucos (Bawa \& Ashton, 1991). Um dos parâmetros reprodutivos que influencia significativamente na distribuição da variabilidade genética de uma espécie é o fluxo gênico, que nas plantas superiores ocorre através da dispersão de pólen e de sementes. Enquanto a mutação, a deriva e a seleção atuam favorecendo a diferenciação genética de populações locais, o fluxo gênico age no sentido oposto à essa diferenciação (Slatkin, 1987).

Nos últimos anos a evolução e disponibilização de técnicas de biologia molecular têm contribuído significativamente para investigações cada vez mais detalhadas da diversidade genética de vários organismos. Vários métodos baseados em PCR (Polymerase Chain Reaction) foram desenvolvidos para acessar a variação genética ao nível do DNA (Karp et al., 1997). Nos últimos anos, a acessibilidade e transferibilidade dos primers entre as espécies são características que fizeram o RAPD (Random Amplified Polymorphic DNA) uma técnica amplamente utilizada em estudos de diversidade genética em populações naturais (Gillies et al., 1997; Cardoso et al., 1998). Um entendimento mais completo da estrutura e dinâmica de populações de plantas, principalmente no que se refere a padrões de fluxo gênico, pode ser obtido se o estudo da variabilidade no DNA nuclear, de herança biparental, for complementado com 
o estudo do DNA de cloroplasto (cpDNA), de herança geralmente uniparental (Comes \& Abbott, 1998).

O genoma do cloroplasto das plantas terrestres é uma molécula circular e pequena, variando de 120 a $217 \mathrm{~kb}$. Sua estrutura é bem documentada, caracterizada na maior parte das espécies por uma "repetição invertida" de cerca de $25 \mathrm{~Kb}$, que divide o restante do genoma em duas regiões de cópia única, sendo uma maior $(\sim 87 \mathrm{~kb})$ e uma menor ( 18kb) (Palmer, 1985). O cpDNA é uma molécula altamente conservada, com baixa taxa de substituição de nucleotídeos. As mudanças ocorrem principalmente no tamanho do genoma, através da adição de novas sequências ou deleção de sequências existentes, geralmente pequenas, envolvendo de 1 a 10 pares de bases localizados em regiões não codificadoras (Palmer, 1987).

O uso mais frequente do DNA de cloroplasto tem sido para estudos ao nível interespecífico, isso devido à lenta evolução desta molécula e consequente baixo polimorfismo dentro de espécies (Palmer, 1987; Birky, 1988). No entanto, alguns estudos revelaram que a diversidade intraespecífica no cpDNA, ocorrendo principalmente em regiões não codificadoras, pode ser suficiente para estudos populacionais (Soltis et al., 1992; El Mousadick \& Petit, 1996). Taberlet et al. (1991) desenvolveram primers universais que tornaram possível a amplificação, via PCR e sequenciamento direto de três dessas regiões não codificadoras. Aliado ao sequenciamento automático, este desenvolvimento aumentou significativamente a resolução do cpDNA intraespecífico, já que permitiu a mudança dos dados RFLP para a análise ao nível de troca de bases na sequência e a detecção de pequenas inserções/deleções.

O genoma de cloroplasto, na maior parte das angiospermas é herdado maternalmente e portanto, o seu fluxo gênico é principalmente por sementes. Já o DNA nuclear possui herança biparental, é sujeito a recombinação e o fluxo gênico é via pólen e sementes, o que aumenta as possibilidades de intercâmbio deste genoma entre indivíduos de uma espécie.enquanto (Sears, 1980; Corriveau \& Coleman; 1988).

O objetivo deste trabalho foi investigar as contribuições da dispersão de pólen e semente na distribuição da variabilidade genética de aroeira em sua área de ocorrência 
no Brasil Central. Para este fim, comparou-se a partição da variação genética entre e dentro de populações em sequências específicas do DNA de cloroplasto e marcadores nucleares RAPD.

\subsection{MATERIAL E MÉTODOS}

4.2.1 Material vegetal e extração do DNA. Foram coletadas sementes de indivíduos de 5 populações de aroeira localizadas em diferentes pontos de sua área de distribuição no Cerrado brasileiro. Foram amostradas sementes de 8 indivíduos das populações de Minas Gerais (MG), Bahia (BA), São Paulo (SP) e Mato Grosso do Sul (MS) e 7 da população localizada em Goiás (GO), totalizando 39 amostras. Em casa de vegetação, cerca de 5 sementes de cada acesso foram plantadas e monitoradas até obtenção de mudas com folhas verdadeiras de tamanho suficiente para a extração do DNA (aproximadamente aos 3-4 meses de idade). Cerca de $150 \mathrm{mg}$ de tecido foliar foi extraído DNA genômico total segundo o protocolo de Doyle \& Doyle (1990). O DNA extraído foi quantificado em gel de agarose $0,8 \%$ corado com brometo de etídeo, utilizando DNA de fago Lambda de concentração conhecida como padrão de comparação.

4.2.2 Reações RAPD. Oito amostra de aroeira foram utilizadas para testar 165 oligonucleotídeos iniciadores "primers" (Operon Technologies). Foram selecionados 27 primers que forneceram marcadores mais polimórficos e com melhor resolução. Os primers selecionados foram utilizados em reações RAPD com as 39 amostras. Os marcadores polimórficos e com resolução clara e reproduzível foram registradas em planilha no formato binário ( 1 - presença de banda e 0 - ausência de banda). Utilizando o programa NTSYS 2.0 (Rohlf, 1990) foi gerada uma matriz de similaridade genética utilizando o coeficiente de Dice (1945). Um agrupamento por UPGMA (Unweighted Pair Group Method with Arithmetic Mean) foi utilizado para representar a similaridade 
genética entre os indivíduos. O programa Arlequin 1.1 (Schneider et al., 1997) foi utilizado para se fazer uma Análise de Variância Molecular (AMOVA, Excoffier et al., 1992) decompondo a variância entre populações e entre indivíduos dentro de populações.

4.2.3 Análise de cpDNA. Foi analisado o polimorfismo de sequência de segmentos amplificados via PCR de regiões não codificadoras do DNA de cloroplasto. Foram testados seis oligonucleotídeos iniciadores "primers" universais desenvolvidos por Taberlet et al. (1991) para análise de DNA de cloroplasto. Para o estudo foi selecionado o segmento amplificado com o par de primers $\mathrm{C}$ (sequência: 5'CGAAATCGGTAGACGCTACG-3') e D (sequência:5'-GGGGATAGAGGGA CTTGAAC-3') amplificando o intron do gene tmL (UAA), com aproximadamente 500 pares de bases. A reação de PCR deste segmento para cada um dos 39 indivíduos foi preparada para um volume total de 25 ul, contendo: $5 \mathrm{ng}$ de DNA; $3 \mathrm{uM}$ de cada primer; 3,9 mg/ml de BSA; 0,2 mM de cada dNTP; 19,5mM de Tris $\mathrm{HCl}(\mathrm{pH} 8,4) ; 48,78 \mathrm{mM}$ de $\mathrm{KCl} ; 2,4 \mathrm{mM}$ de $\mathrm{MgCl}$; 1,5 unidade de Taq polimerase. A amplificação ocorreu obedecendo os seguintes parâmetros: desnaturação inicial a $94^{\circ} \mathrm{C}$ por 4 minutos, seguida de 30 ciclos de desnaturação a $92^{\circ} \mathrm{C}$ por 45 segundos, anelamento a $56^{\circ} \mathrm{C}$ por 45 segundos, extensão a $72^{\circ} \mathrm{C}$ por 3 minutos e uma extensão final de 10 minutos a $72^{\circ} \mathrm{C}$. A amplificação dos segmento alvo foi verificada em eletroforese em gel de agarose a $1 \%$, utilizando-se 3 ul de reação. Para verificar o tamanho previsto do fragmento amplificado foi utilizado o padrão de fragmentos de tamanho conhecido $1 \mathrm{~Kb}$ ladder (Gibco). A fim de se eliminar excessos de desoxinucleotídeos e primers não incorporados na reação de amplificação, o DNA obtido passou por um processo de purificação através de precipitação com etanol absoluto, seguida de uma lavagem adicional com etanol $70 \%$. A reação de PCR para o sequenciamento do fragmento purificado foi preparada utilizando um dos primers (primer D) e o kit Dyedeoxy Terminator (Perkin Elmer), em que cada desoxinucleotídeo é marcado com uma fluorescência diferente. Após a amplificação, os fragmentos foram novamente purificados e em seguida sequenciados utilizando o sequenciador automático ABI 377 (Perkin Elmer). As sequências de 370 
bases foram primeiramente alinhadas utilizando o programa Wisconsin Package Version 9.0, Genetics Computer Group (GCG), Madison, Wisc. e em seguida um alinhamento manual foi feito nas sequências alinhadas pelo programa. Este procedimento melhorou o alinhamento feito pelo GCG e foi feito consultando-se os eletroferogramas do sequenciamento para se corrigir os possiveis erros de leitura. Foi feita uma AMOVA com base nos dados de sequenciamento de cpDNA dos 39 indivíduos utilizando o programa Arlequin 1.1 (Schneider et al., 1997)

4.2.4 Análise de polimorfismo de inserção no cpDNA. O sequenciamento do cpDNA revelou a presença de uma inserção/deleção de uma sequência de 6 pares de bases em alguns indivíduos. O polimorfismo de inserção em um total de 192 indivíduos de aroeira distribuídos em vários pontos dos estados de MG, GO, BA e PI foi verificado utilizando eletroforese vertical em gel de poliacrilamida. Como amostras controle foram utilizadas duas das amostras anteriormente sequenciadas, sendo uma de Selvíria (MS), que não apresentava a inserção e outra de Alexandre Mascarenhas (MG), que apresentava a inserção de seis bases. A reação de PCR foi feita utilizando-se o par de primers C e D e a amplificação conferida em gel de agarose 1,5\%. Uma alíquota de 3ul do DNA amplificado foi aplicado em gel de poliacrilamida desnaturante $4 \%$ contendo uréia $7 \mathrm{M}$. A eletroforese foi conduzida com potência constante de 1500 Watts por 2 horas. A deteç̧ão de fragmentos foi realizada com nitrato de prata, segundo o protocolo de Bassam et al. (1991) utilizando o padrão de fragmentos de tamanho conhecido $1 \mathrm{~Kb}$ ladder (Gibco).

\subsection{RESULTADOS}

4.3.1 Marcadores nucleares RAPD. Após a triagem de 165 "primers" foram selecionados os seguintes 27: OPA20, OPG14, OPJ9, OPJ10, OPJ11, OPJ16, OPK16, OPL1, OPL5, OPL8, OPL12, OPL17, OPL18, OPN4, OPN6, OPR3, OPR15, OPW6, 
OPW19, OPX6, OPX8, OPY2, OPY3, OPY7, OPY13, OPZ18 e OPZ19. Estes primers geraram 83 marcadores RAPD polimórficos e facilmente interpretáveis. A análise de agrupamento por UPGMA revelou que não existe um padrão claro de estruturação dos indivíduos de acordo com a origem geográfica, sugerindo existir ampla diversidade dentro de populações (Figura 5). As populações de São Paulo e Mato Grosso do Sul estão separadas das demais a cerca de $63 \%$ de similaridade e dentro deste grupo os indivíduos também estão distribuídos sem estrutura definida por populações. A AMOVA baseada nos marcadores RAPD mostrou que a maior parte $(82 \%)$ da variabilidade desses indivíduos de aroeira está dentro de populações, embora exista diferenciação significativa entre as populações $(18 \%, \mathrm{P}<0,0001)$ (Tabela 3$)$.

Tabela 3. Análise de Variância Molecular (AMOVA) baseada em marcadores RAPD de 39 indivíduos de 5 populações de aroeira.

\begin{tabular}{lccccc}
\hline Fonte de variação & G.L. & S.Q. & Comp. Va.r & $\%$ Total & $p^{(l)}$ \\
\hline Entre Populações & 4 & 127,930 & 2,575 & 17,78 & $<0,0001$ \\
Dentro de Populações & 34 & 404,839 & 11,907 & 82,22 & \\
\hline Total & 38 & 532,769 & 14,482 & \\
\hline $\begin{array}{l}\text { (1) Probabilidade de o valor estimado do componente de variação ser ao acaso. Teste realizado por 1000 } \\
\text { permutações. }\end{array}$
\end{tabular}




\subsubsection{Polimorfismo de sequência de cpDNA. Fragmentos com o tamanho previsto} de aproximadamente 500 pares de bases foram amplificados com sucesso com os primers universais utilizados em todos os indivíduos. Não foi observado polimorfismo de comprimento de fragmentos na verificação da amplificação em gel de agarose. Uma leitura completa de cerca de 500 bases foi obtida. A partir do fragmento de cpDNA foram utilizadas 370 bases para o alinhamento, evitando-se o início e o final da sequência, onde a leitura não é eficiente (Figura 6A). O nível de polimorfismo de sequência encontrado entre os indivíduos foi muito reduzido. Durante o alinhamento manual, seguindo os eletroferogramas do sequenciamento, verificou-se que algumas das trocas ou ausência/presença de bases eram devidas a erros de leitura cometidos pelo sequenciador e não a polimorfismos reais. Estes potenciais artefatos foram checados através de reamplificação e resequenciamento dos produtos. Apesar do reduzido nível de polimorfismo de sequências, foi verificada a ocorrência de uma inserção/deleção de um "motif" de seis pares de bases, acompanhada de uma transição C-T. Todos os indivíduos das populações da Bahia e de Minas Gerais apresentaram a inserção 5'GAAAAA-3' enquanto todos os indivíduos de São Paulo, Mato Grosso do Sul e Goiás, não apresentaram esta inserção. Nas populações com a inserção, a base que seguiu a sequência inserida foi uma citosina, enquanto as demais apresentaram uma timina. A AMOVA feita com base nos dados do sequenciamento destes 39 indivíduos demonstrou que cerca de $94 \%$ da variabilidade molecular para esta sequência está contida entre as populações e apenas $6 \%$ é devida à variância dentro das populações (Tabela 4). A análise do polimorfismo de inserção/deleção em gel de poliacrilamida de alta resolução (Figura 6B) foi consistente com os dados de sequenciamento. Duas regiões podem ser claramente distinguidas de acordo com a presença ou ausência da inserção (Figura 7). Todos os 82 indivíduos localizados na região oeste não possuem a inserção, enquanto todos os 110 indivíduos localizados a leste apresentam esta característica. Além deste, não foi observado qualquer outro polimorfismo de comprimento nos 192 indivíduos analisados, sugerindo que esta parece ser a única fonte de variação de comprimento nesta região genômica do cloroplasto desta espécie. 
Tabela 4. Análise de Variância Molocular (AMOVA) de 39 indivíduos de 5 populações de aroeira baseada em polimorfismo de sequência no intron do gene trnL (UAA) do DNA de cloroplasto.

\begin{tabular}{cccccc}
\hline Fonte de Variação & G.L. & S.Q.. & Comp. Var. & $\%$ Total & $p^{(1)}$ \\
\hline Entre Populações & 4 & 66,968 & 2,130 & 93,84 & $<0,0001$ \\
Dentro de Populações & 34 & 4,750 & 0,139 & 6,16 & \\
\hline Total & 38 & 71,718 & 2,269 & & \\
\hline
\end{tabular}

(1) Probabilidade de o valor estimado do componente de variação ser ao acaso. Teste realizado por 1000 permutações.

\subsection{DISCUSSÃO}

A análise de polimorfismo de DNA nuclear demostrou que a maior parte da variabilidade genética de aroeira está contida dentro de populações. Apesar de alguns dos 83 marcadores RAPD poderem, a princípio, ter sido amplificados a partir do genoma de organelas, a grande maioria deles é mais provavelmente derivada de polimorfismos do DNA nuclear. Isto é devido à maior complexidade deste genoma em relação ao do cloroplasto aumentar suas chances de perfeito anelamento ao sítio do primer (Williams et al., 1993). A ausência de um agrupamento claro dos indivíduos em populações no dendrograma indica que indivíduos de populações diferentes podem estar tão ou mais próximos geneticamente do que aqueles pertencentes a uma mesma população. Esta tendência é confirmada e quantificada pela AMOVA, onde $82 \%$ da variância está contida dentro de populações. Estes resultados estão de acordo com o comportamento esperado. No caso do DNA nuclear, o fluxo gênico ocorre via dispersão de sementes e pólen. A aroeira é uma espécie dióica e, como na maioria das espécies tropicais, a ação do fluxo gênico tende a diminuir a diferenciação entre as populações (Loveless \& 
Hamrick, 1984; Bawa, 1992). Resultados similares foram encontrados por Moraes (1992) e Lacerda (1997), que reportaram que a maior parte da variabilidade genética em locos izoenzimáticos é encontrada dentro de populações de aroeira. A concordância entre os padrões de estrutura de populações revelados por marcadores RAPD e isoenzimas sugerem que a manutenção da variabilidade genética nesta espécie é mais provavelmente devida a forças evolutivas neutras do que à seleção.

Em contraste claro à distribuição de variabilidade encontrada para o genoma nuclear, foi verificada uma diferenciação significativa entre populações para o DNA de cloroplasto. A AMOVA revelou que essencialmente, a mesma quantidade de variabilidade encontrada dentro de populações para o DNA nuclear foi encontrada entre populações para a região do cpDNA analisada. A AMOVA baseada em 370 caracteres (pares de bases) no DNA de cloroplasto e a distribuição geográfica dos indivíduos em que a presença do marcador foi constatada pela eletroforese revelam uma forte estruturação geográfica do cpDNA. De acordo com a AMOVA, cerca de $94 \%$ da variância está entre as populações. Resultados semelhantes foram encontrados em outros trabalhos com angiospermas, utilizando polimorfismos de fragmentos de restrição de cpDNA. Petit et al. (1993) encontraram $86,3 \%$ da variabilidade entre populações de carvalho na Europa; Soltis et al. (1989) estudaram 352 sítios de restrição no cpDNA de Tolmiea menziesii e não encontraram variação dentro de populações. Byrne \& Moran (1994) obtiveram um alto nivel de diversidade em Eucalyptus nitens e atribuíram a maior parte da variabilidade à variação entre populações e regiões.

A diferenciação das populações para cpDNA foi baseada principalmente em um polimorfismo de comprimento de 6 pares de bases em um segmento de 500 pares de bases. Esses resultados mostraram que possibilidade de sequenciamento automático direto de um produto de PCR constitui uma tática poderosa na revelação de polimorfismos de comprimento no genoma do cloroplasto de plantas para estudos intraespecíficos. Embora a descoberta deste marcador tenha ocorrido com base em sequenciamento, este trabalho mostrou ainda que a sua detecção pode ser realizada de forma rápida e simples em um gel de poliacrilamida após a amplificação do fragmento via PCR utilizando os primers universais. 
Embora bastante útil nos níveis interespecíficos ou intergenéricos, acreditavase que a alta taxa de conservação do cpDNA impossibilitaria seu uso em níveis taxonômicos inferiores. No entanto Harris \& Ingran (1991) citam vários trabalhos que reportam variação intraespecífica e até intrapopulacional no cpDNA de diversas espécies. A maior parte das variações no cpDNA tem sido observada no comprimento de fragmentos de restrição ou amplificação, envolvendo principalmente sequências pequenas, de 1 a 10 pares de bases (Palmer, 1987, McCauley, 1994) e existem estudos que indicam a possibilidade de obtenção de marcadores de cpDNA para estudos intraespecíficos (MacCauley, 1995; Levy et al. 1996). Os resultados deste trabalho corroboraram os estudos anteriores, demonstrando que, no caso da aroeira, a inserção/deleção encontrada representa um marcador genético extremamente útil na identificação regional de acessos de aroeira para conservação, manejo e utilização de germoplasma.

$\mathrm{Na}$ grande maioria das angiospermas a herança do cpDNA é maternal (Sears, 1980) e portanto o fluxo gênico ocorre exclusivamente através da dispersão de sementes. Apesar de a herança exclusivamente maternal do cpDNA em aroeira não tenha sido testada formalmente, os resultados sugerem ser esta uma premissa válida. Embora de evolução lenta, o acúmulo de mutações no DNA de cloroplasto tende a aumentar a diferenciação entre populações. Somente em eventos raros de dispersão de sementes a distâncias mais longas ocorreria uma oportunidade de haver fluxo gênico. A semente de aroeira é dispersa pelo vento e por gravidade, o que segundo Loveless \& Hamrick (1984) limita a migração a longas distâncias e pode explicar a estruturação geográfica observada para a variação do cpDNA.

A comparação de estruturação da variabilidade genética para os dois tipos de genoma permite o entendimento da influência da dispersão do pólen e da semente na distribuição da variabilidade dentro uma espécie (McCauley, 1995, Cruzan, 1998). Neste estudo, a baixa diferenciação genética entre populações para o DNA nuclear contrastando com a alta diferenciação para o cpDNA indica claramente uma contribuição significativamente maior da polinização no intercâmbio genético entre as populações. McCauley (1994) fez um estudo da estrutura de populações de uma 
angiosperma dióica (Silene alba) utilizando cp DNA e isoenzimas. Pela análise de polimorfismos de comprimento de fragmentos de restrição de produtos amplificados do cpDNA, estimou um $F_{S T}$ de 0,67 para o cpDNA e 0,13 para as isoenzimas, indicando que o efeito do fluxo de pólen foi o principal responsável pela redução do $\mathrm{F}_{\mathrm{ST}}$ nuclear.

Uma evidência da importância da polinização na aproximação genética das populações de aroeira envolve a comparação da variação nos marcadores RAPD e cpDNA das populações de São Paulo, Mato Grosso do Sul e Goiás. Enquanto todos os indivíduos dessas três populações não possuem a inserção no cpDNA (Figura 7), o dendrograma obtido a partir dos dados RAPD (DNA nuclear) mostra a clara separação das populações de São Paulo e Mato Grosso do Sul, mas a população de Goiás se agrupa junto com as populações de Minas Gerais e Bahia, que possuem a inserção (Figura 5). Considerando a herança maternal do cpDNA em angiospermas, a baixa diferenciação genética para o DNA nuclear sugere ser o fluxo de pólen o responsável pelo aumento da similaridade genética entre a população de Goiás e os indivíduos de Minas Gerais e Bahia. Ao nível do DNA de cloroplasto entretanto, a diferenciação continua.

\subsection{CONCLUSÕES}

A distribuição geográfica da inserção detectada no cpDNA de aroeira constitui um marcador importante para estudos de fluxo gênico via sementes em escala regional. A distribuição da variabilidade genética para este marcador comparada à variação para marcadores RAPD possibilitou a constatação da maior contribuição da polinização em relação dispersão de sementes no fluxo gênico dessa espécie. Entretanto, uma análise mais detalhada da estruturação geográfica da variabilidade para cpDNA somente seria possível ao se analisar regiões significativamente mais polimórficas deste genoma. O DNA de cloroplasto de plantas apresenta regiões de sequências simples repetidas (SSR) de mononucleotídeos. Esses microssatélites podem ser amplificadas a partir de regiões flanqueadoras altamente conservadas e têm se tornado uma ferramenta cada vez mais 
utilizada para estudos de processos que determinam a distribuição geográfica da variabilidade genética em populações naturais (Powell et al., 1995b,c). Esta técnica abriu novas e mais refinadas possibilidades de estudos de dispersão de sementes ao nível de indivíduos dentro de populações e/ou populações contíguas e devem ser agora o foco de atenção na continuidade do estudo com populações de aroeira. Enquanto o polimorfismo de inserção detectado constitui um marcador útil para a diferenciação em escala regional, SSR's de cpDNA devem proporcionar o entendimento preciso do movimento da semente em uma escala local. 


\section{CONCLUSÕES GERAIS}

As principais conclusões deste trabalho foram:

1. A distribuição da variabilidade genética no DNA nuclear de aroeira (Myracroduon urundeuva) segue o padrão esperado para uma espécie arbórea tropical dióica. Maior proporção da variabilidade genética é encontrada dentro de populações. Embora pequena, a diferença existente entre as populações é significativa.

2. A proporção da variabilidade genética existente dentro de famílias de aroeira é alta (75-89\%) e representa uma porção significativa da variabilidade genética encontrada nas populações. Este fato indica que a coleta de sementes visando a conservação $e x$ situ deve continuar considerando a estrutura de famílias.

3. Existe uma correlação significativa entre distância geográfica e distância genética. Uma pequena, porém significativa parte da variabilidade genética nesta espécie pode portanto ser explicada pela distância geográfica entre os indivíduos.

4. A análise das sequências do cpDNA revelou a presença de uma inserção/deleção de 6 pares de bases acompanhada de uma transição C-T no fragmento amplificado. Esta inserção constitui um marcador extremamente útil para estudos de fluxo gênico via sementes em escala regional.

5. A pouca diferenciação entre as populações para os marcadores nucleares RAPD contrastando com a forte estruturação geográfica para o DNA de cloroplasto indicam uma maior contribuição da polinização no fluxo gênico entre populações de aroeira.

6. Os resultados obtidos fornecem subsídios importantes para o delineamento de estratégias de conservação in situ ou ex situ da aroeira. A congruência entre as distribuições da variabilidade nas zonas de coleta do banco de germoplasma e as 
populações propriamente ditas validam a representatividade genética do banco de germoplasma estudado. Futuras expedições de coleta ou o estabelecimento de reservas genéticas poderão concentrar esforços em coletar ou conservar um maior número de indivíduos em um número reduzido de áreas de ocorrência da espécie distantes entre si. 
ANEXO: FIGURAS 


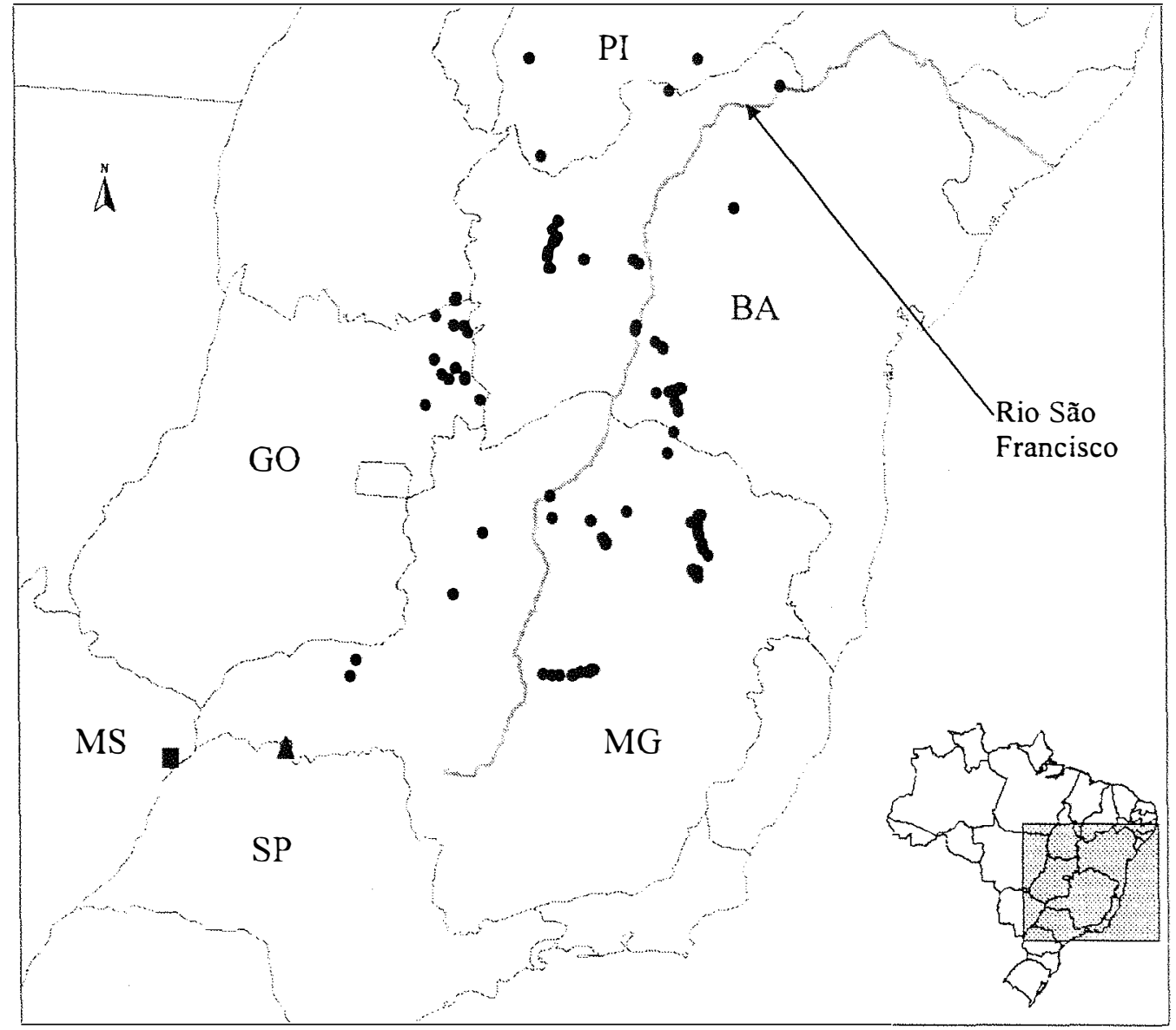

Figura 1 - Localização geográfica das áreas de coleta dos acessos de aroeira (•) e das

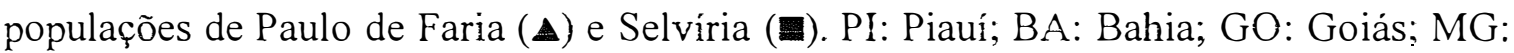
Minas Gerais; SP: São Paulo e MS: Mato Grosso do Sul. 


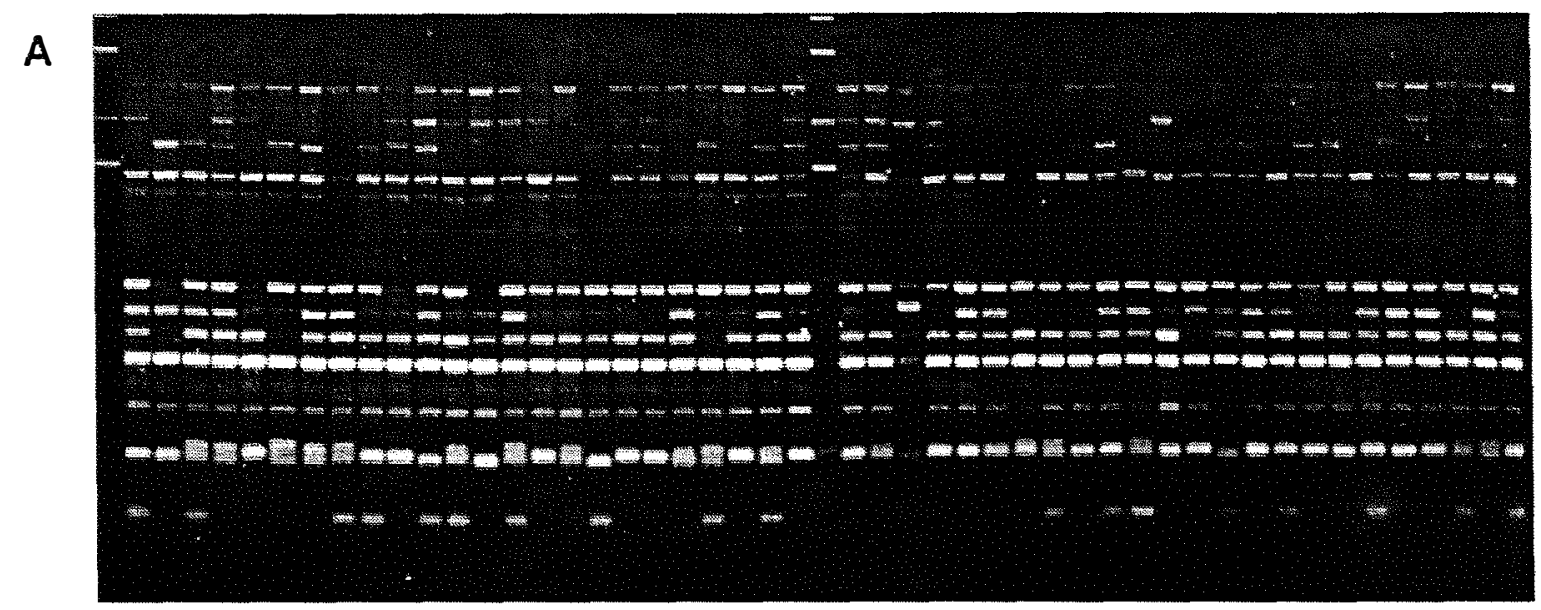

B

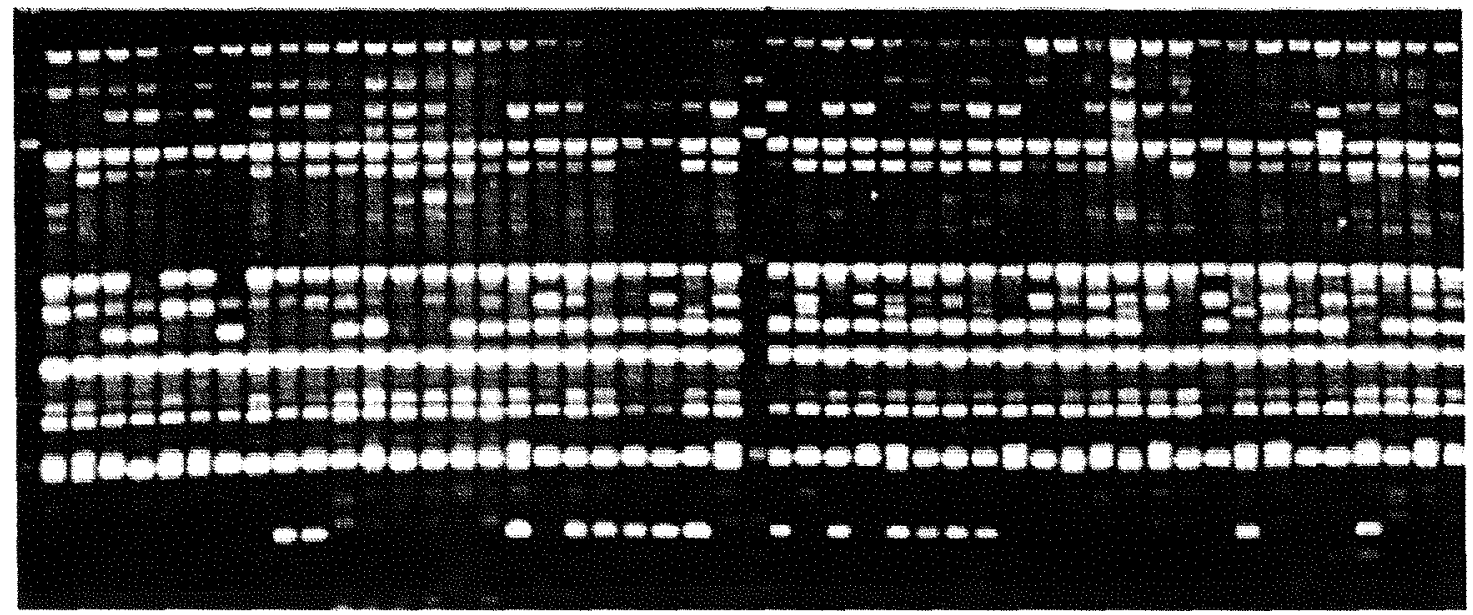

Figura 2 - Géis RAPD de indivíduos de aroeira utilizando o primer OPY7. Painel (A): 48 indivíduos amostrados aleatoriamente de diferentes zonas de coleta. Painel (B): 48 indivíduos, sendo 16 meio-irmãos de cada uma de 3 famílias de polinização aberta. As pistas 1 e 26 nos dois painéis correspondem ao padrão de fragmento de tamanho conhecido Ladder $1 \mathrm{~kb}$ (Gibco). 

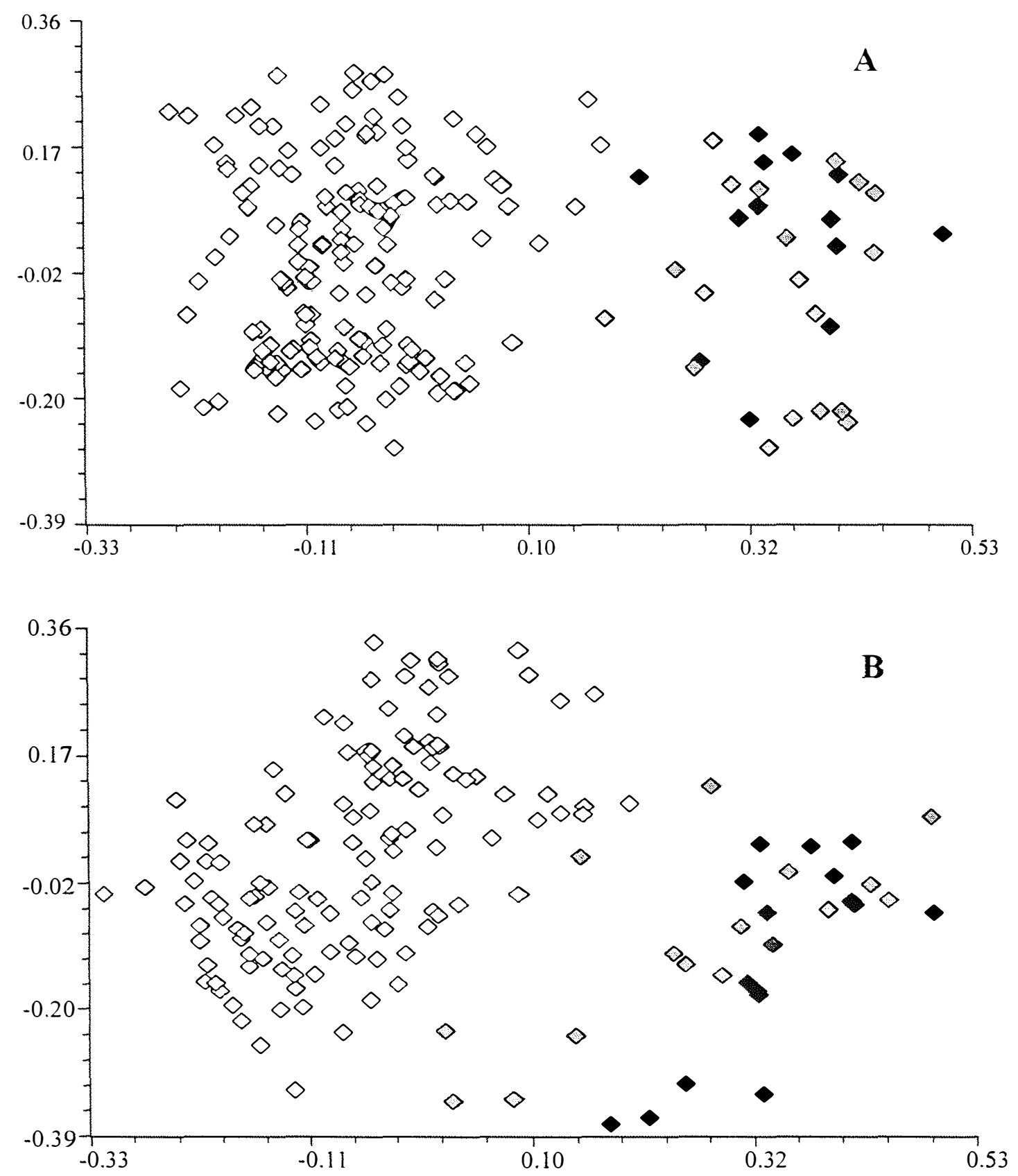

Figura 3 - Análise de Coordenadas Principais (PCO) de indivíduos de aroeira de acordo com a similaridade genética. (A): Individuos das zonas de coleta $(\diamond)$, população de Paulo de Faria $($ ) e população de Selvíria $($ ). (B): Indivíduos de 8 famílias de polinização aberta das zonas de coleta $(\diamond)$ e 2 familias de Paulo de Faria ( $\bullet$ and $\bullet$ ). 


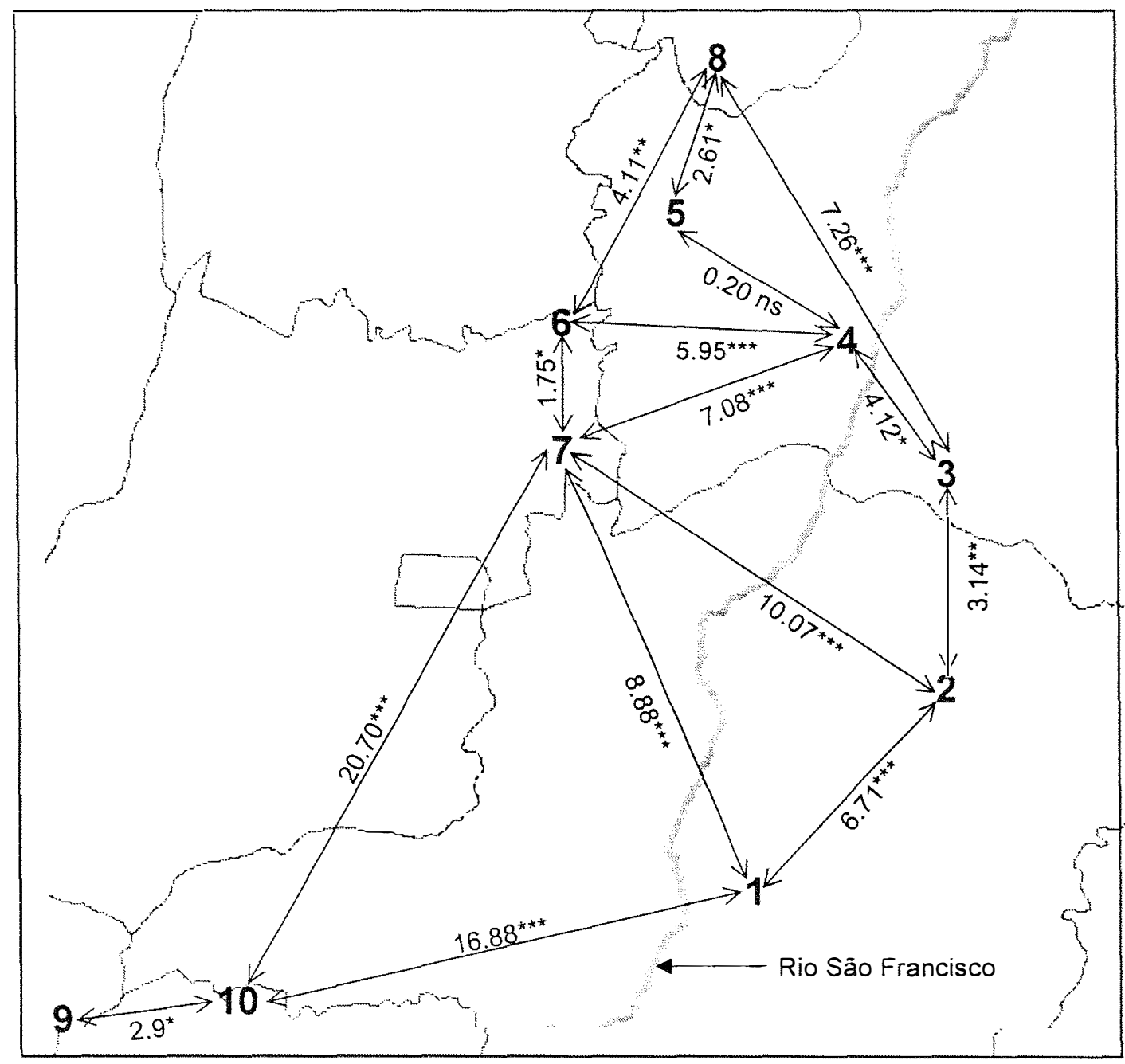

Figura 4 - Proporções da variabilidade genética total atribuída à variância entre algumas zonas de coleta de aroeira por AMOVA. ${ }^{* * *}(\mathrm{p} \leq 0,001) ;{ }^{* *}(\mathrm{p} \leq 0,005) ;{ }^{*}(\mathrm{p} \leq 0,05)$ e ns (não significativo). 


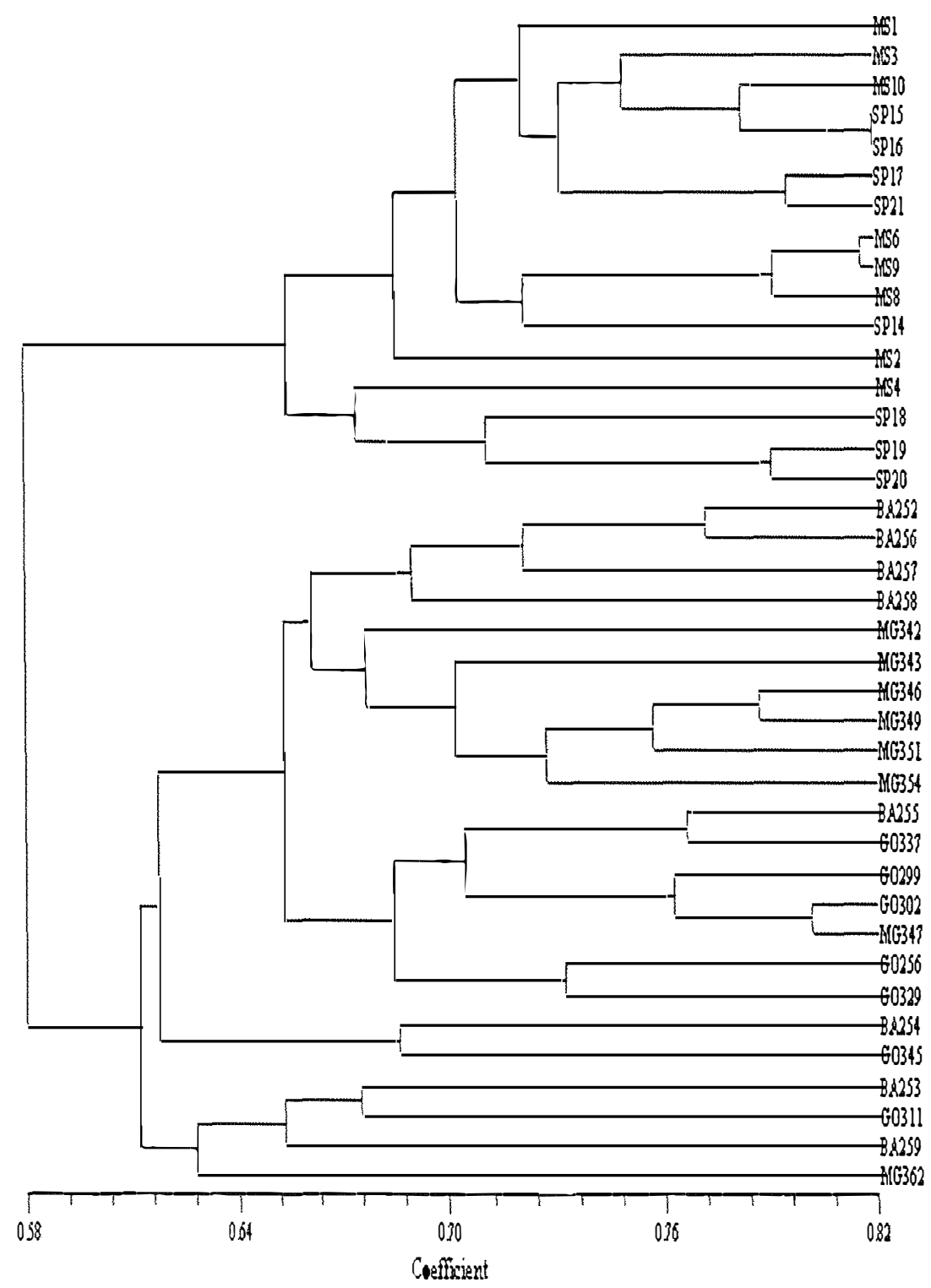

Figura 5 - Análise UPGMA de indivíduos de aroeira baseada em similaridade de Dice estimada com marcadores RAPD. MS, SP, MG, BA e GO são siglas para as 5 populações amostradas. 

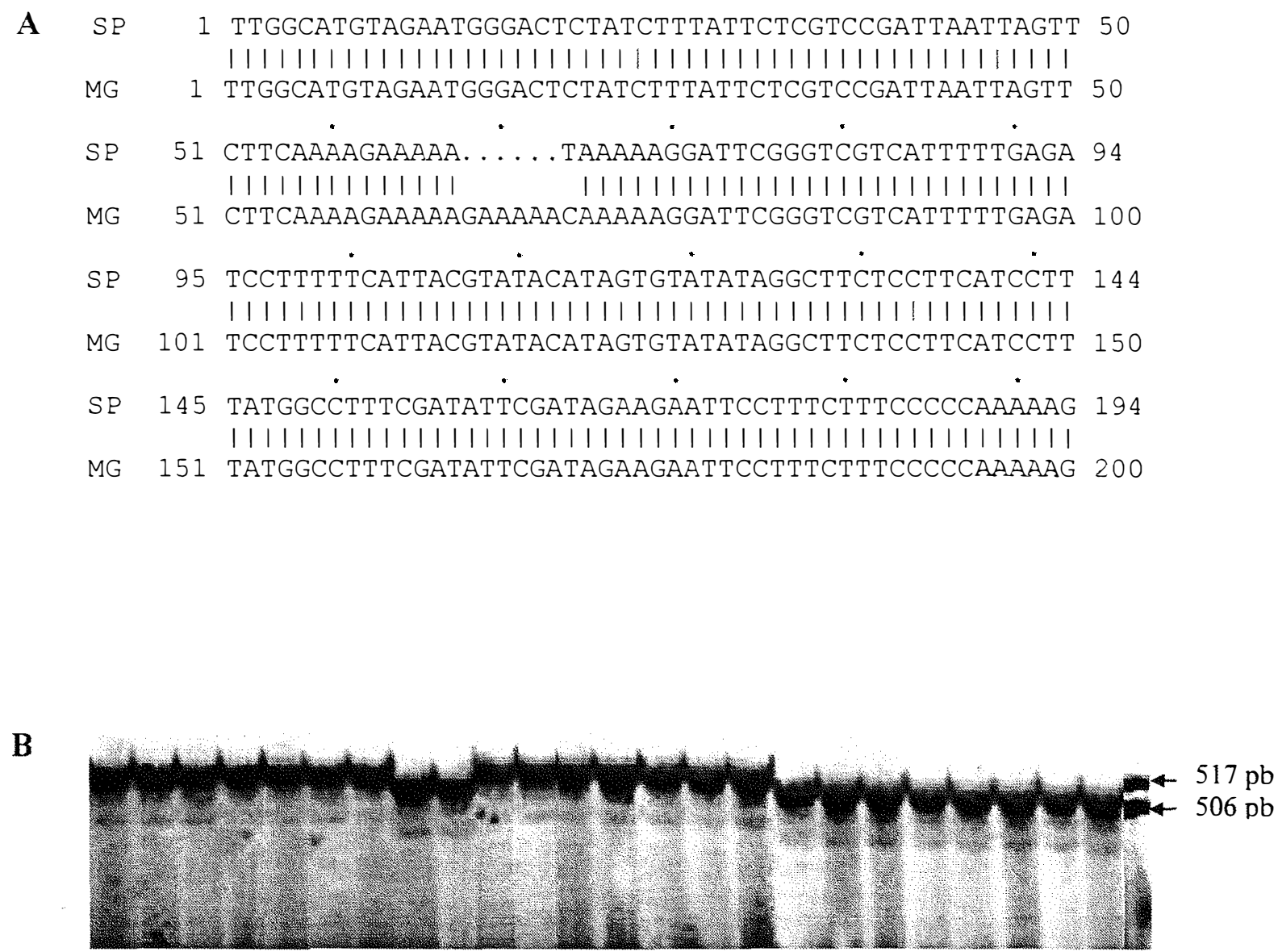

Figura 6 - Polimorfismo de inserção/deleção no intron do gene trnL (UAA) encontrado no cpDNA de aroeira. (A) Alinhamento de parte das sequências entre um indivíduo de São Paulo (SP) (ausência da inserção) e um de Minas Gerais (MG) (presença da inserção); (B) Gel de Poliacrilamida corado com prata mostrando polimorfismo de comprimento: Pistas 1 a 7 e 10 a 16 correspondem a indivíduos de MG e BA, pistas 8, 9 e 17 a 24 correspondem a indivíduos de GO e SP; a pista 25 corresponde ao padrão de fragmento de tamanho conhecido Ladder $1 \mathrm{~kb}$ (Gibco) 


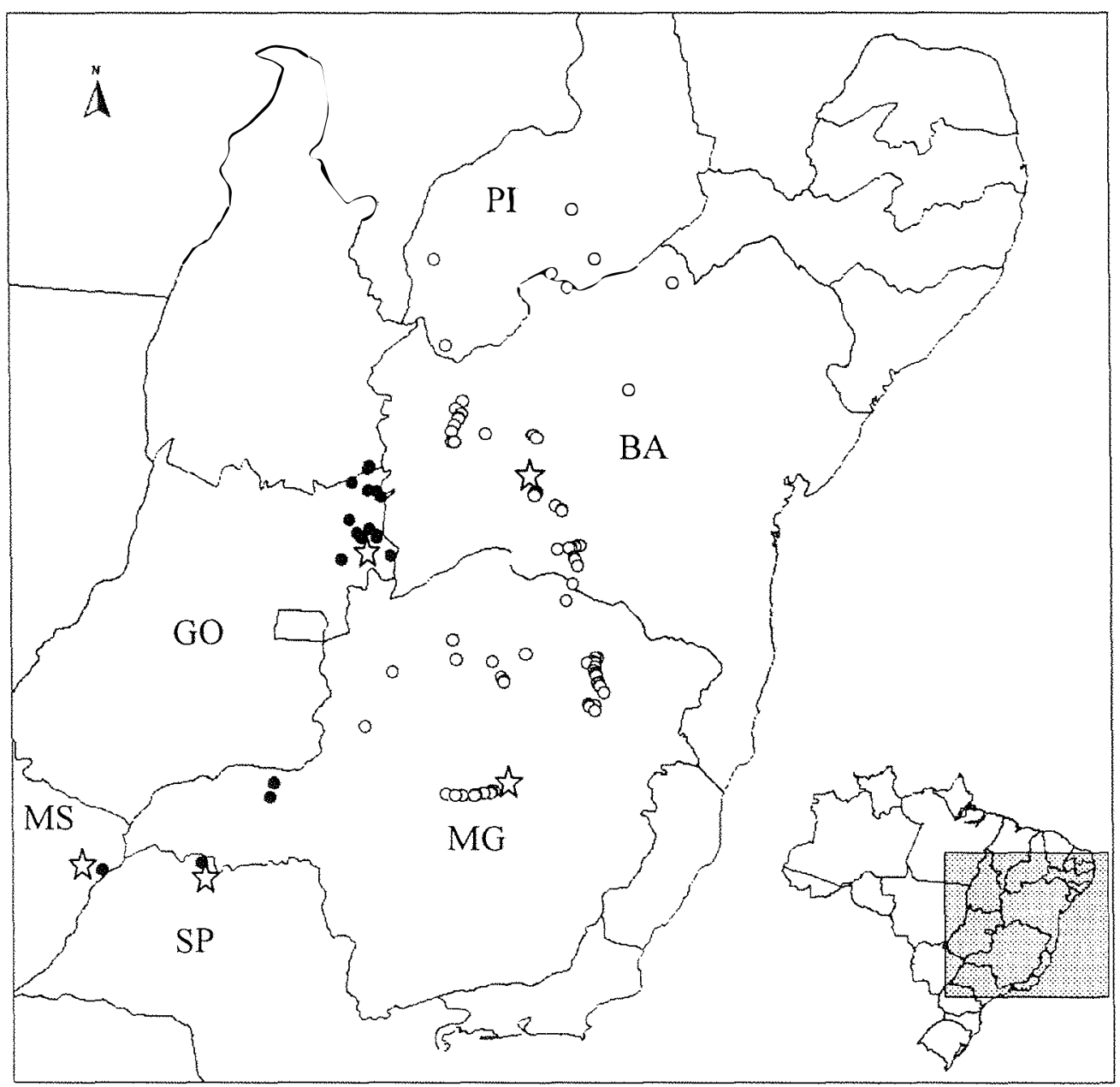

Figura 7 - Distribuição do polimorfĩsmo de inserção no cpDNA de aroeira: (\#) presença da inserção, (!) ausência da inserção. ‘j indicam a localização das populações amostradas para o sequenciamento. 


\section{REFERÊNCIAS BIBLIOGRÁFICAS}

ALLARD, R.W. Princípios do melhoramento genético das plantas. Blucher Ltda. $1971.381 \mathrm{p}$.

ALLEN, A.C. Estudo da biologia reprodutiva de duas espécies florestais (aroeira e gonçalo alves) da região do cerrado. Brasília: EMBRAPA, 1991. 5p. (Boletim de pesquisa em andamento, n.2).

ANDERSEN, W.R.; FAIRBANKS, D.J. Molecular markers: Important tools for plant genetic resource characterization. Diversity, v. 6, n. 3\&4, p. 51-53, 1990.

BANKS, J.A.; BIRK Jr, C.W. Chloroplast DNA diversity is low in a wild plant, Lupinus texensis. Proceedings of the National Academy of Sciences (USA), v. 82, p. 6950-6954, 1985.

BASSAN, B.J.; CAETANO-ANOLLÉS, G.; GRESSHOFF, P.M. Fast and sensitive silver staining of DNA in polyacrylamide gels. Analytical Biochemistry, v. 196, p. 80-83, 1991.

BAWA, K.S. Mating systems, genetic differentiation and speciation in tropical rain forest plants. Biotropica, v.24, n.2b, p. 250-255, 1992.

BAWA, K.S.; ASHTON, P.S. Conservation of rare trees in tropical rain forests: A genetic perspective. In: FALK, D.D. \& HOLSINGER, K.E. (eds). Genetic and conservation of rare plants. New York: Oxford University Press, 1991, p. 62-71.

BIRKY Jr., C.W. Evolution and variation in plant chloroplast and mitochondrial genomes. In: Gottlieb, L.D.; Jain, S.K. (Ed.) Plant evolutionary biology. New York: Chapman \& Hall, 1988. p. 23-53.

BOWMAN, C.M.; BONNARD, G.; DYER, T.A. Chloroplast DNA variation between species of Triticum and Aegilops: Location of the variation on the chloroplast 
genome and its relevance to the inheritance and classification of the cytoplasm.

Theoretical and Applied Genetics, v. 65; p. 247-262.

BOYLE, T.J.B.; YEH, F.C. Within-population genetic variation - implications for selection and breeding. In: MORGENSTERN, E,K. \& BOYLE, T.J.B. (eds.) Proceedings of the twenty-first meeting of the canadian tree improvement association. part 2: Symposium on tree improvement-progressing together. Truro, N.S, 1987. p. 20-42.

BYRNE, M.; MORAN, G.F. Population divergence in the chloroplast genome of Eucalyptus nitens. Heredity, v.73, p.18-28, 1994.

CAETANO-ANOLLÉS, G. Scanning of nucleic acids by in vitro amplification. New developments and applications. Nature Biotechnoly. v.14, p. 1668-1674, 1996.

CARDOSO, M.A.; PROVAN, J.; POWELL, W.; FERREIRA, P.C.G.; OLIVEIRA, D.E. High genetic differentiation among remnant populations of the endangered Caesalpinia echinata Lam. Molecular Ecology,v.7, p.601-608,1998.

CLEGG, M.T.; ZURAWSKI, G. Chloroplast DNA and the study of plant phylogeny: present status and future prospects. In: SOLTIS, P.S.; SOLTIS, D.E., DOYLE, J.J. (eds). Molecular systematics of plants. New York: Chapman \& Hall, 1992, p. 113.

COMES, HP; ABBOTT, R.J. The relative importance of historical events and gene flow on the population structure of a Mediterranean ragwort, Senecio gallicus (Asteraceae). Evolution, v.52, n.2, 355-367, 1998.

CORRIVEAU, J.L.; COLEMAN, A.W. Rapid screening methods to detect potential biparental inheritance of plastid DNA and results of over 200 angiosperm species. American Journal of Botany, v. 75, p. 1443-1458, 1988.

CRUZAN, M.B. Genetic markers in plant evolutionary ecology. Ecology, v.79, n.2, p. 400-412, 1998.

DICE, L.R. Measures of the amount of ecologic association between species. Ecology, v.26, p. 297-302, 1945.

DOYLE, J. J.: DOYLE J.L. Isolation of plant DNA from fresh tissue. Focus v.12, p.13$15,1990$. 
EL MOUSADICK, A; PETIT, R.J. Chloroplast DNA phylogeography of the argan tree of Morocco. Molecular Ecology,v.5, p.547-555, 1996.

ELLSWORTH, D.L.; RITTENHOUSE, K.D.; HONEYCUTT, R.L. Artifactual variation in randomly amplified polimorphic DNA banding patterns. Biotechniques, v. 14, n.2, p. 214-217, 1993.

ERIKSSON, G.; NAMKOONG, G.; ROBERDS, J.H. Dynamic conservation for uncertain futures. Forest Ecology and Management, v.62, p.15-37, 1993.

EXCOFFIER, L.; SMOUSE, P.E.; QUATTRO, J. M. Analysis of molecular variance inferred from metric distances among DNA haplotypes: application to human mitochondrial DNA restriction data. Genetics, v.131, p.479-491, 1992.

FAO. Recursos fitogenéticos: su conservación in situ para el uso humano. Roma, 1989. $38 \mathrm{p}$.

FERREIRA, M.E.; GRATTAPAGLIA, D. Introdução ao uso de marcadores moleculares em análise genética. Brasília: EMBRAPA/CENARGEN, 1995. $220 \mathrm{p}$.

FORD-LLOYD, B.V.; JACKSON, M.T.; NEWBURY, H.J. Molecular markers and the management of genetic resources in seed genebanks: a case study of rice. In: CALLOW, J.A.; FORD-LLOYD, B.V. \& NEWBURY, H.J. (eds). Biotechnology and plant genetic resources: Conservation and use. U.K.: CAB International, 1997. cap.5, p. 103-118.

GILLIES, A.C.M.; CORNELliUS, J.P.; NEWTON, A.C.; NAVARRO, M.; HERNADEZ, M.; WILSON,J. Genetic variation in Costa Rican populations of the tropical timber species Cedrela odorata L., assessed using RAPDs. Molecular Ecology, v. 6, p. 1133-1145, 1997.

GRATTAPAGLIA, D.; SEDEROFF, R.R. Genetic linkage maps of Eucalyptus grandis and E. urophylla using a pseudo-testcross strategy and RAPD markers. Genetics, v. 137, p.1121-1137, 1994.

HAMRICK, J.L. The distribution of genetic variation within end among natural forest population. In: SCHONEWALD-COX, C.M. et alii. Genetic and Conservation. New York: The Benjamin/cummings, 1983. p. 335-348. 
HAMRICK, J.L.; GODT, M.J.W.; MURAWSKI, D.A.; LOVELESS, M.D. Correlations between species traits and allozyme diversity: implications for conservation biology. In: FALK, D.A. \& HOLSINGER, K.E (ed). Genetics and Conservation of Rare Plants. NewYork: Oxford University Press, 1991. p. 75-86.

HARRIS, S.A.; INGRAN, R. Chloroplast DNA and biosystematics: The effects of intraspecific diversity and plastid transmission. Taxon, v.40, p. 393-412, 1991.

HOGBIN, P. M.; AYRE, D.J.; WHELAN, R.J. Genetic variation and reproductive success of road verge populations of the rare schrub Grevillea barklyana (Proteaceae). Heredity, v.80, p.180-186, 1998.

HUFF, D.R.; PEAKALL R.; SMOUSE, P.E. RAPD variation within and among natural populations of outcrossing buffalograss (Buchloe dactyloides (nutt.) Engelm.). Theoretical and Applied Genetics, v. 86, p. 927-934, 1993.

INSTITUTO BRASILEIRO DO MEIO AMBIENTE E DOS RECURSOS NATURAIS RENOVÁVEIS - IBAMA. Lista oficial de espécies da flora brasileira ameaçadas de extinção. Diário Oficial, Brasília, 23 de janeiro de 1992. p. 869-873.

KAGEYAMA, P.Y. Conservação "in situ" de recursos genéticos de plantas. IPEF, n. 35, p. 7-37. 1987.

KAGEYAMA, P.Y. Genetic structure of tropical tree species of Brazil. In: BAWA, K.S. \& HADLEY, M. (eds.) Reproductive ecology of tropical forest plants. Paris: UNESCO., 1990. p. 375-387.

KAGEYAMA, P.Y.; DIAS, I.S. Aplicação da genética em espécies florestais nativas. Silvicultura em São Paulo, v. 16, parte 2, p. 782-791, 1982.

KAGEYAMA, P.Y.; GANDARA, F.G. Dinâmica de populações de espécies arbóreas: implicações para o manejo e a conservação. In: III Simpósio de Ecossistemas da Costa Brasileira - subsídios a um gerenciamento ambiental. v.2. Mata Atlântica e Ecossistemas Marinhos. Serra Negra. São Paulo, 1994. p. 1-7.

KARP, A.; EDWARDS, KJ.; BRUFORD, M.; FUNK, S.; VOSMAN. B.; MORGANTE, M.; SEBERG, O.; KREMER, A.; BOURSOT, P.; ARCTANDER, P.; TAUTZ, D.; HEWITT, G. Molecular technologies for biodiversity evaluation: Opportunities and challenges - New technologies for detecting variation in DNA 
complement traditional methods in biodiversity. Nature Biotechnology, v. 15, p. 625-628, 1997.

LACERDA, C.M.B. Diversidade genética por isoenzimas em populações de aroeira (Myracrodruon urundeuva Freire, F. \& M.F. Allemão) Anacardiaceae no semiárido. Piracicaba, 1997. 81p. Dissertação (Mestrado) - Escola Superior de Agricultura "Luíz de Queiroz", Universidade de São Paulo.

LEVY, F.; ANTONOVICS, J.; BOYNTON, J.E.; GILLHAN, N. A population genetic analysis of chloroplast DNA in Phacelia. Heredity, v.76, 143-155, 1996.

LORENZI, H. Árvores brasileiras: manual de identificação e cultivo de plantas arbóreas do Brasil. São Paulo: Ed. Plantarum, 1992. 368 p.

LOVELESS, M.D.; HAMRICK, J.L. Ecological determinants of genetic structure in plant populations. Annual Review of Ecology Systematics, n.15, p. 65-95, 1984.

MAGUIRE, T.L.; CONRAN, J.G.; COLlinS, G.G.; SEDGLEY, M. Molecular analysis of interspecific and intergeneric relationships of Banksia using RAPDs and non coding chloroplast DNA sequences. Theoretical and Applied Genetics, v.95, p. 253-260, 1997.

MAGUIRE, T.L.; SEDGLEY, M. Genetic diversity in Banksia and Dryandra (Proteaceae) with emphasis on Banksia cuneata, a rare and endangered species. Heredity, v.79, p.394-401, 1997.

MANTEL. N.A. The detection of disease clustering and a generalized regression approach. Cancer Research, v.27, p.209-220. 1967.

McCAULEY, D.E. Contrasting the distribution of chloroplast DNA and allozyme polymorphism among local populations of Silene alba: Implications for studies of gene flow in plants. Proccedings of the National Academy of Sciences of the USA, v. 91, p. 8127-8131, 1994.

McCAULEY, D.E. The use of chloroplast DNA polymorphism in studies of gene flow in plants. Tree, v. 10, p. 198-202, 1995.

MORAES, M.L.T. de. Variabilidade genética por isoenzimas e caracteres quantitativos em duas populações naturais de aroeira Myracrodruon urundeuva F.F. \& M.F. Allemão - Anacardiaceae (Syn: Astronium urundeuva (Fr. Allemão) Engler). 
Piracicaba, 1992. 139p. Tese (Doutorado) - Escola Superior de Agricultura Luiz de Queiroz - Universidade de São Paulo.

M' RIBU, K. H. ; HILU, K. W. Application of random amplified polymorphic DNA to study genetic diversity in Paspalum scrobiculatum L. (Kodo millet, Poaceae). Genetic Resources and Crop Evolution, v. 43, p. 203-210, 1996.

NASON, J.D.; HAMRICK, J.L. Reproductive and genetic consequences of forest fragmentation: two case studies of neotropical canopy trees. Journal of Heredity, v. 88, p. $264-276,1997$.

- NEI, M.; LI, W.H. Mathematical model for studying genetic variation in terms of restriction endonucleases. Proceedings of the National Academy of Science USA, v.76, p.5269-5273, 1979.

NESBITT, K.A.; POTTS, B.M.; VAILLANCOURT, R.E.; WEST, A.K.; REID, J.B. Partitioning and distribution of RAPD variation in a forest tree species, Eucalyptus globulus (Myrtaceae). Heredity, v. 74, p. 628-637, 1995.

NOGUEIRA, J.C.B.; SIQUEIRA, A.C.M.F.; MORAIS, E.; SALLES, L.M.A.B. Conservação dos recursos genéticos da aroeira - Astronium urundeuva (Fr. All.) Engl. In: $5^{\circ}$ Congresso Florestal Estadual. Nova Prata-RS, 1984. v.2, p. 291-295, NOGUEIRA, J.C.B.; SIQUEIRA, A.C.M.F.; MORAIS, E.; YWANE, M.S.S. Testes de progênies e procedências de aroeira - Astronium urundeuva (Fr. All.) Engl. Boletim Técnico do Instituto Florestal de São Paulo, v. 40 a, n.2, p.367-377, 1986.

OLMSTEAD, R.G.; PALMER, J.D. Chloroplast DNA systematics: A review of methods and data analysis. American Journal of Botany, v.81, p. 1205-1224, 1994.

PALMER, J.D. Comparative organization of chloroplast genomes. Annual Review of Genetics, v.19, p. 325-354, 1985.

PALMER, J.D. Chloroplast DNA evolution and biosystematic uses of chloroplast DNA variation. The American Naturalist, v.130, p. S6-S29, July, 1987. 
PARKER, P. G.; SNOW, A. A.; SCHUG, M.D.; BOOTON, G.C.; FUERST, P.A. What molecules can tell us about populations: choosing and using a molecular marker. Ecology, v.79, n.2, p.361-382, 1998.

PETIT, R.J.; KREMER, A.; WAGNER, D.B. Geographic structure of chloroplast DNA polymorphisms in European oaks. Theoretical and Applied Genetics, v. 87, p. 122-128, 1993

POWELL, W.; OROZCO-CASTILlO, C.; CHALMERS, K.J.; PROVAN, J.; WAUGH, R. Polymerase chain reaction-based assays for the characterization of plant genetic resources. Electrophoresis, v.16, p. 1726-1730, 1995a.

POWELL,W.; MORGANTE, M.; ANDRE, C.; McNICOL, J.W.; MACHRAY, G.C.; DOYLE, J.J.; TINGEY, S.V.; RAFALSKI, J.A. Hypervariable microsatellites provide a general source of polymorphic DNA markers for the chloroplast genome. Current Biology, v.5, n.9, p.1023-1029, 1995b.

POWELL,W.;MORGANTE, M.; McDEVITT, R.; VENDRAMIN, G.G.; RAFALSKI, J.A. Polymorphic simple sequence repeat regions in chloroplast genomes: Applications to the populations genetics of pines. Proceedings of the National Academy of Science USA, v.92, p. 7759-7763, 1995c.

RAFALSKI, J.N.; VOGEL, J.M.; MORGANTE, M.; POWELL, W.; ANDRE, C.; TINGEY, S.V. Generating and using DNA markers in plants. In: BIRREN, B.; LAI, E. (Ed.). Nonmammalian genomic analysis: A practical guide. Academic Press, 1996. p. 75-133.

RIBEIRO, J.F.; SANO, S.M.; MACÊDO, J.; SILVA, J.A.da. Os principais tipos

fitofísionômicos da Região dos Cerrados. Brasília: EMBRAPA/CPAC, 1983. 28

p. (Boletim de Pesquisa n. 21).

RIBEIRO, J.H. Durável além de uma vida. Globo Rural, v. 5, n.49, p. 85-90, 1989.

RIZZINI, C.T. Árvores e madeiras úteis do Brasil: manual de dendrologia brasileira. São Paulo. Ed. Edgard Blucher Ltda., 1971. 294 p.

ROHLF, F.J. NTSYS-pc numerical taxonomy and multivariate analysis system. vers. 2.0. Exeter Software, Setauket, NY, 1997. 
ROSSETTO, M.; WEAVER, P.K.; DIXON, K.W. Use of RAPD analysis in devising conservation strategies for the rare and endangered Grevillea scapigera (Proteaceae). Molecular Ecology, v.4, p.321-329, 1995.

SALOMÃO, A.N.; LEITE, A.M.C. Comportamento de regenerantes de Astroniun urundeuva (Fr. All.) Engler em área sob ação antrópica. Acta Botanica Brasilica, v.6, n.2, p. 85-96, 1993.

SANTIN, D.A. Revisão taxonômica do gênero Myracrodruon Fr. All. (Anacardiaceae). Campinas, 1989. 178p. Dissertação (Mestrado) - Universidade Estadual de Campinas.

SCHNEIDER, S.; KUEFFER, J.M.; ROESSLI, D.; EXCOFFIER, L. Arlequin Ver.

1.1: A software for population genetic data analysis. Genetics and Biometry Laboratory, University of Geneva, Switzerland, 1997.

SEARS, B.B. Elimination of plastids during spermatogenesis and fertilization in the plant kingdom. Plasmid, 4, p. 233-255, 1980.

SHEELY, D.L.; MEAGHER, T.R. Genetic diversity in micronesian island populations of the tropical tree Campnosperma brevipetiolata (Anacardiaceae). American Journal of Botany, v. 83, n. 12, p.1571-1579, 1996.

SLATKIN, M. Gene flow and the geographic of natural populations. Science, 236, p. 787-792, May. 1987.

SOLTIS, D.E.; SOLTIS, P.S.; RANKER, T.A.; NESS, B.D. Chloroplast variation in a wild plant, Tolmiea menziesii. Genetics, 121, p. 819-826, 1989.

SOLTIS, D.E.; SOLTIS, P.S.; MILLIGAN, B.G. Intraspecific chloroplast DNA variation: systematic and phylogenetic implications. In: SOLTIS , D. E. ; SOLTIS, P. S.; DOYLE, J. (Ed.) Molecular systematics of plants. New York: Chapman \& Hall, 1992. p. 117-150.

TABERleT, P.; GIELlY, L.; PAUTOU, G.; BOUVET, J. Universal primers for amplification of three non-coding regions of chloroplast DNA. Plant Molecular Biology, v.17, p. 1105-1109, 1991.

TINGEY, S.T.; DELTUFFO, J.P. Genetic analysis with Random Amplified Polymorphic DNA markers. Plant Physiology, v. 101, p. 349-352, 1993. 
WAUGH, R.; POWELL, W. Using RAPD markers for crop improvement. Tibtech, v.10,6p, 1992.

WESTMAN, A.L.; KRESOVICH, S. Use of molecular marker techniques for description of plant genetic resources. In: CALLOW, J.A.; FORD-LLOYD, B.V.; NEWBURY, H.J. (eds). Biotechnology and plant genetic resources: Conservation and use. U.K.: CAB International, 1993. Cap. 2, p. 9-48.

WILLIAMS, J.G.K; HANAFEY, M.K.; RAFALSKI, J.A; TINGEY, S.V Genetic analysis using Randon Amplified Polymorphic DNA markers. Methods in Enzimology, v.218, p. 704-740, 1993.

WILLIAMS, J.G.; KUBELIK, A.R.; LIVAK, K.J.; RAFALSKI, J.A.; TINGEY, S.V. DNA polymorphism amplified by arbitrary primers are useful as genetic markers. Nucleic Acids Research, v. 18, p. 6531-6535, 1990.

YEH, F.C.; CHONG, K.D.X.; YANG, R.C. RAPD variation within and among natural populations of trembling aspen (Populus tremuloides - Michx.) from Alberta. Journal of Heredity, v.86, p. 454-460, 1995.

ZURAWSKI, G.; CLEGG, M.T.; BROWN, H.D. The nature of nucleotide sequence divergence between barley and maize chloroplast DNA. Genetics, v. 106, p. 735$749,1984$. 